Review

\title{
Documentation of Archaeology-Specific Workflow for Airborne LiDAR Data Processing
}

\author{
Edisa Lozić ${ }^{1}$ and Benjamin Štular ${ }^{2, *(D)}$ \\ 1 Institute of Classics, University of Graz, Universitätsplatz 3/II, 8010 Graz, Austria; edisa.lozic@uni-graz.at \\ 2 Research Centre of the Slovenian Academy of Sciences and Arts, Novi trg 2, 1000 Ljubljana, Slovenia \\ * Correspondence: benjamin.stular@zrc-sazu.si
}

check for updates

Citation: Lozić, E.; Štular, B.

Documentation of ArchaeologySpecific Workflow for Airborne LiDAR Data Processing. Geosciences 2021, 11, 26. https://doi.org/ 10.3390/geosciences11010026

Received: 1 December 2020 Accepted: 31 December 2020 Published: 5 January 2021

Publisher's Note: MDPI stays neutral with regard to jurisdictional clai$\mathrm{ms}$ in published maps and institutional affiliations.

Copyright: ( 2021 by the authors. Licensee MDPI, Basel, Switzerland. This article is an open access article distributed under the terms and conditions of the Creative Commons Attribution (CC BY) license (https:// creativecommons.org/licenses/by/ $4.0 /)$.

\begin{abstract}
Airborne LiDAR is a widely accepted tool for archaeological prospection. Over the last decade an archaeology-specific data processing workflow has been evolving, ranging from raw data acquisition and processing, point cloud processing and product derivation to archaeological interpretation, dissemination and archiving. Currently, though, there is no agreement on the specific steps or terminology. This workflow is an interpretative knowledge production process that must be documented as such to ensure the intellectual transparency and accountability required for evidencebased archaeological interpretation. However, this is rarely the case, and there are no accepted schemas, let alone standards, to do so. As a result, there is a risk that the data processing steps of the workflow will be accepted as a black box process and its results as "hard data". The first step in documenting a scientific process is to define it. Therefore, this paper provides a critical review of existing archaeology-specific workflows for airborne LiDAR-derived topographic data processing, resulting in an 18-step workflow with consistent terminology. Its novelty and significance lies in the fact that the existing comprehensive studies are outdated and the newer ones focus on selected aspects of the workflow. Based on the updated workflow, a good practice example for its documentation is presented.
\end{abstract}

Keywords: archaeological prospection; airborne LiDAR; method; workflow; documentation

\section{Introduction}

Airborne LiDAR is nowadays a widely accepted tool for archaeological prospection, e.g., [1,2]. With a combination of perception and comprehension [3,4] archaeologists interpret enhanced visualizations of high-resolution raster elevation models that have been interpolated from processed airborne LiDAR data. The results have proven to be an excellent tool for detecting archaeological features worldwide, especially in forested areas, e.g., recently, [5-9]. More importantly, mapping of features makes it possible to develop a more profound understanding of the archaeological landscapes [10]. In comparison to other fields, the use of airborne LiDAR-derived data in archaeology is specific in several ways [11]. Therefore, an archaeology-specific airborne LiDAR data processing workflow from mission planning to archiving has been developed.

However, this process is rarely documented and there are no accepted schemas, let alone standards, to do so. As a result, there is a risk that airborne LiDAR data processing from data acquisition to product derivation is accepted as a black box process and its results as "hard data" [11-16]. Unfortunately, this has become the norm rather than the exception. We see researchers processing their own data, referring to the airborne LiDAR-derived data visualization (LiDAR visualizations for short [17]) as a "LiDAR image" without providing any further information. Sometimes, the situation is further exacerbated by editorial guidelines and/or the peer review process, which consider the description of the airborne LiDAR data processing to be irrelevant. This leads to the insufficient understanding or misunderstanding of archaeology-specific airborne LiDAR data processing, which is 
an important, long-standing problem that hinders the development of airborne LiDAR in archaeology.

Why documenting? Two of the most important criteria for conducting any modern scientific research are replicability and reflexivity. Producing high-quality documentation ensures that the data can be understood now and in the future. It ensures that the data can be interpreted post facto as the relevant context becomes available, as is so often the case in archaeology. Quantitative research focuses on replicability, while qualitative research usually centers on reflexivity [18]. The research process should be made transparent for third parties and the published results must be replicable and understandable [19]. Currently, the existing literature on the subject specific to airborne LiDAR in archaeology is scarce and particularistic $[20,21]$. However, the necessity for the standardized documentation of the research process is well understood in the field of computer-based visualization of cultural heritage. Airborne LiDAR data is arguably a subset of this field, but significantly, it shares the key aspect of the knowledge production process: the workflow is composed by decisions based on various sets of input data that are interpreted and integrated. This introduces subjectivity, that, if not correctly reported, compromises the validity of the outcomes and their capacity to be understood and evaluated [22]. Therefore, the incorporation of metadata (data about data) and paradata (documentation of process) is crucial to ensure scientific transparency [23]. It also informs users about not only what they are looking at but also how decisions were made and how the data sources were used to make those decisions [24]. Or, in the words of The London Charter for the Computer-Based Visualisation of Cultural Heritage, metadata and paradata are used to clarify the relationship between research sources, implicit knowledge, explicit reasoning, and visualization-based outcomes [22]. In addition, documenting is also the cornerstone of FAIR data sharing [25,26], especially for archaeological geospatial data [17].

How to document? The first step towards documenting any scientific process is to define it. An archaeology-specific airborne LiDAR data processing workflow from mission planning to archiving has been presented in several studies (Table 1). The first introduction to the archaeology-specific workflow for airborne LiDAR data processing in archaeology by Crutchley in 2010 [27] was aimed at archaeologists in general, not at LiDAR specialists. It remains one of the most complete overviews of the workflow. However, it leaves out some important steps, most notably several steps of point cloud processing. Nevertheless, it was written with an in-depth knowledge of the process, and the text remains a useful starting point for newcomers to the field. The first scientific presentation of the workflow was written by Doneus and Briese [16]. It describes the entire process and is most detailed in describing archaeology-specific data acquisition. This is the seminal study that also provides the backbone for our article. Doneus and Kühteiber [13] and Opitz [28] published chapters in the monograph volume aimed at providing a general overview of airborne LiDAR in archaeology. The first focused on archaeological interpretation and the latter on all other aspects of the workflow. Unfortunately, the terminology between the two texts was not consistent, and the content was too dispersed to become a major influence. Fernandez Diaz [29] was the first to use the Mesoamerican data to illustrate the workflow. It is by far the most complete analysis of archaeology-specific raw data acquisition and processing. Until the sensor technology changes radically this text will retain its importance. Stular and Lozić [20] focused on point cloud data processing for a specific set of off-the-shelf general purpose data. Perhaps the most important aspect of the study was to demonstrate that with archaeology-specific data processing, general purpose data of seemingly too low quality can be successfully used in archaeology. Grammer et al. [21] focused on archaeological interpretation and were the first to point out the importance of data integration. Doneus et al. [15] focus on presenting a specific ground point filtering method, but they present a concise yet refreshed overview of the entire workflow as well. 
Table 1. Previously published archaeology-specific airborne LiDAR data processing workflows. Acronyms: d.—data; c.—classification; f.—filtering.

\begin{tabular}{|c|c|c|c|c|c|c|c|c|c|c|}
\hline Phase & & Step & [27] & [16] & [28] & [13] & [29] & [20] & [21] & [15] \\
\hline \multirow{7}{*}{$\begin{array}{c}\text { Raw data } \\
\text { acquisition \& } \\
\text { processing }\end{array}$} & 1.1 & $\begin{array}{c}\text { project } \\
\text { planning }\end{array}$ & $\begin{array}{l}\text { project } \\
\text { planning }\end{array}$ & & & & flight planning & & & project planning \\
\hline & 1.2 & $\begin{array}{c}\text { system } \\
\text { calibration }\end{array}$ & & choice of sensor & & & $\begin{array}{c}\text { system } \\
\text { configuration }\end{array}$ & & & system calibration \\
\hline & 1.3 & $\begin{array}{c}\text { data } \\
\text { acquisition }\end{array}$ & d. acquisition & d. acquisition & d. acquisition ${ }^{1}$ & d. acquisition & d. collection & d. acquisition ${ }^{1}$ & & d. acquisition \\
\hline & 1.4 & registering & registering & geo-referencing & correlation & d. processing & $\begin{array}{c}\text { trajectory } \\
\text { determination }\end{array}$ & & & geo-referencing \\
\hline & & & & & & & calibration & & & \\
\hline & & & & & & & $\begin{array}{l}\text { point cloud } \\
\text { production }\end{array}$ & & & \\
\hline & 1.5 & $\begin{array}{c}\text { strip } \\
\text { adjustment }\end{array}$ & grid alignment & & strip alignment & & project binning & & & $\begin{array}{l}\text { flight strip } \\
\text { adjustment }\end{array}$ \\
\hline \multirow{7}{*}{$\begin{array}{c}\text { Point cloud } \\
\text { processing \& } \\
\text { Derivation of } \\
\text { products }\end{array}$} & 2.1 & $\begin{array}{l}\text { automatic } \\
\text { ground point } \\
\text { classification }\end{array}$ & filtering & filtering & $\begin{array}{l}\text { classification } \\
\text { (automatic) }\end{array}$ & d. processing & $\begin{array}{l}\text { ground point } \\
\text { classification }\end{array}$ & $\begin{array}{l}\text { ground point } \\
\text { filtering }\end{array}$ & & $\begin{array}{l}\text { classification/ground } \\
\text { point filtering }\end{array}$ \\
\hline & 2.2 & $\begin{array}{l}\text { object-type } \\
\text { classification }\end{array}$ & & & & & $\begin{array}{l}\text { object-type } \\
\text { point } \\
\text { classification }\end{array}$ & & & \\
\hline & 2.3 & $\begin{array}{l}\text { manual reclas- } \\
\text { sification }\end{array}$ & & & $\begin{array}{c}\text { manual } \\
\text { classification }\end{array}$ & & & $\begin{array}{c}\text { manual } \\
\text { classification }\end{array}$ & & \\
\hline & 2.4 & $\begin{array}{c}\text { DFM } \\
\text { interpolation }\end{array}$ & interpolation & & interpolation & d. processing & $\begin{array}{l}\text { surface model } \\
\text { generation }\end{array}$ & interpolation & & DTM interpolation \\
\hline & 2.5 & $\begin{array}{c}\text { Enhanced } \\
\text { visualization }\end{array}$ & visualisation & visualisation & visualization & visualisation & d. visualization & visualization & visualizations & visualization \\
\hline & & & & & & & $\begin{array}{l}\text { quality and } \\
\text { accuracy } \\
\text { assessment }\end{array}$ & & & \\
\hline & & & & & & & $\begin{array}{l}\text { confidence of } \\
\text { features }\end{array}$ & & & \\
\hline
\end{tabular}


Table 1. Cont.

\begin{tabular}{|c|c|c|c|c|c|c|c|c|c|c|}
\hline Phase & & Step & [27] & [16] & [28] & [13] & [29] & [20] & [21] & [15] \\
\hline \multirow{5}{*}{$\begin{array}{l}\text { Archaeological } \\
\text { interpretation }\end{array}$} & 3.1 & $\begin{array}{c}\text { data } \\
\text { integration }\end{array}$ & & & & & & & d. integration & \\
\hline & 3.2 & $\begin{array}{l}\text { interpretative } \\
\text { mapping }\end{array}$ & mapping & $\begin{array}{c}\text { manual } \\
\text { detection }\end{array}$ & & $\begin{array}{l}\text { interpretative } \\
\text { mapping }\end{array}$ & d. mapping ${ }^{1}$ & $\begin{array}{l}\text { archaeological } \\
\text { interpretation }{ }^{1}\end{array}$ & $\begin{array}{l}\text { interpretative } \\
\text { mapping }\end{array}$ & \\
\hline & 3.3 & groundassessme & ht field survey & & & $\begin{array}{l}\text { ground } \\
\text { inspection }\end{array}$ & $\begin{array}{c}\text { ground } \\
\text { validation }\end{array}$ & & $\begin{array}{c}\text { ground- } \\
\text { observation }\end{array}$ & \\
\hline & 3.4 & $\begin{array}{c}\text { deep' }^{\prime} \\
\text { interpretation }\end{array}$ & $\begin{array}{l}\text { additional } \\
\text { uses (GIS) }\end{array}$ & & & $\begin{array}{c}\text { 'Deep', } \\
\text { integrated } \\
\text { multi-scale } \\
\text { interpretation }\end{array}$ & & & & \\
\hline & & $\begin{array}{l}\text { automated } \\
\text { mapping }\end{array}$ & & $\begin{array}{l}\text { automatic } \\
\text { detection }\end{array}$ & & & & & & \\
\hline \multirow{2}{*}{$\begin{array}{l}\text { Dissemination } \\
\text { \& Archiving }\end{array}$} & 4.1 & $\begin{array}{c}\mathrm{d} . \\
\text { management }\end{array}$ & & documentation & d. management & & & & & \\
\hline & 4.2 & dissemination & dissemination & & dissemination & & & & & \\
\hline
\end{tabular}


Despite terminological differences, the studies cited agree on the general workflow. However, since both comprehensive overviews [16,27] were written, several new steps or exclusive aspects have been introduced in the studies that focused on raw data [29], point cloud processing [11,15], or on archaeological interpretation [13,21]. As a result, there is currently no agreement on the specific steps or terminology for airborne LiDAR data processing from data acquisition to data archiving in archaeology.

In the view of the above presented scientific background, the first objective of this article is to provide an up-to-date and comprehensive review of the workflow. It will comprise all steps introduced in recent years and it will establish a consistent terminology. The second objective is to demonstrate a good practice example of how the archaeologyspecific workflow for airborne LiDAR data acquisition, processing, and interpretation can be documented. Developing an archaeology-specific metadata and paradata scheme for airborne LiDAR data is beyond the scope of this article, but this study is the necessary first step.

It must be clarified that this article focuses on topographic data of solid ground, because this remains by far the most prevailing use in archaeology.

\section{Materials and Methods}

\subsection{Workflow}

As mentioned in the introduction, the processes or phases of the workflow presented in the early overviews $[16,27]$ have not been challenged at any time and remain operational: raw data acquisition and processing is followed by point cloud processing and derivation of products and then by archaeological interpretation, dissemination, and archiving. The contribution of this article is the compilation of sub-processes or steps that have been presented since in a unified workflow (Table 2).

Table 2. Archaeology-specific airborne LiDAR data processing workflow from mission planning to archiving. Arch (aeological) engagement: o nonessential; + as consultant; ++ important; +++ essential.

\begin{tabular}{|c|c|c|c|c|c|}
\hline & Phase & Step & Workflow Step & Arch. Engagement & References \\
\hline \multirow{5}{*}{1} & \multirow{5}{*}{$\begin{array}{l}\text { Raw data acquisition \& } \\
\text { Processing }\end{array}$} & 1.1 & Project planning & + & {$[15,27,29]$} \\
\hline & & 1.2 & System calibration & o & {$[15,16,29]$} \\
\hline & & 1.3 & Data acquisition & $\mathrm{o}$ & {$[13,15,16,20,27-29]$} \\
\hline & & 1.4 & Registering & + & {$[15,16,27-29]$} \\
\hline & & 1.5 & Strip adjustment & o & {$[15,27-29]$} \\
\hline \multirow{5}{*}{2} & \multirow{5}{*}{$\begin{array}{l}\text { Point cloud processing \& } \\
\text { Derivation of products }\end{array}$} & 2.1 & Automatic ground point classification & ++ & {$[13,15,16,20,27,29]$} \\
\hline & & 2.2 & Object-type classification & ++ & [29] \\
\hline & & 2.3 & Manual reclassification & +++ & {$[20,28]$} \\
\hline & & 2.4 & DFM interpolation & + & {$[15,20,27-29]$} \\
\hline & & 2.5 & Enhanced visualization & +++ & {$[13,15,16,20,21,27-29]$} \\
\hline \multirow{5}{*}{3} & \multirow{5}{*}{$\begin{array}{l}\text { Archaeological } \\
\text { interpretation }\end{array}$} & 3.1 & Data integration & ++ & {$[21]$} \\
\hline & & 3.2 & Interpretative mapping & +++ & {$[13,16,20,21,27,29]$} \\
\hline & & 3.3 & Ground assessment & +++ & {$[13,21,27,29]$} \\
\hline & & 3.4 & 'Deep' interpretation & +++ & {$[13,27]$} \\
\hline & & 3.5 & Automated mapping & ++ & [16] \\
\hline \multirow{3}{*}{4} & \multirow{3}{*}{ Dissemination \& Archiving } & 4.1 & Data management & + & {$[16,28]$} \\
\hline & & 4.2 & Dissemination & + & {$[27,28]$} \\
\hline & & 4.3 & Archiving & + & {$[27,28]$} \\
\hline
\end{tabular}

Below is an overview of each step of the workflow. The steps with ample bibliography are described briefly, whereas some steps are described in more detail. 


\subsection{Raw data Acquisition and Processing (1.1-1.5)}

Raw data acquisition and processing consists of five steps. It needs to be mentioned, that the proposed workflow might be biased towards Riegel sensors, due to the bias in existing archaeology-specific literature.

(1.1) Project planning is important to ensure that the airborne LiDAR survey is tailored to specific scientific research questions [29,30].

(1.2) System calibration ensures that the point density will adequately support the desired raster resolution. In order to achieve this, the requirements of the researcher, local flight conditions and aviation regulations, and the performance specifications of the aircraft must be taken into account to establish an appropriate flight plan and system configuration [29-31].

(1.3) During the data acquisition step, the project plan is followed, but the LiDAR operator often needs to make real-time adjustments to take account of the conditions encountered during the flight [29].

(1.4) The raw data collected —also referred to as the primary data [27]—constitute a series of measurements of the time and intensities of the returned laser pulses. In the data registration step, these data are correlated with the navigation information from the Global Navigation Satellite System (GNSS), the inertial measurement unit (IMU), and the surveyed ground control points (GCP) to calculate the geodetic position of each laser return [31].

(1.5) The primary objective of flight strip adjustment is to provide quality assurance and quality control for the geospatial end product by reducing or ultimately eliminating the discrepancies found in the overlap areas of the strips, thus creating a seamless product [32].

\subsection{Point Cloud Processing and Derivation of the Products (2.1-2.5)}

A note on terminology is appropriate at this point. As noted elsewhere [11], we use the term algorithm to refer to theory (e.g., academic articles) and filter to implementation (e.g., in software). The term filtering is used to describe the process of applying the filter to the data. The ground extraction filters are used to classify each point in the point cloud as either ground or non-ground and no point is deleted (filtered). However, when the DTM is interpolated from the point cloud, only the points classified as the ground are used and the rest are omitted (filtered) from the process. In the past this lead to a certain ambiguity in the terminology, especially concerning the term filter/filtering (e.g., "ground-point filtering" v "ground-point classification").

Point cloud processing and the derivation of the products consists of the next five steps.

(2.1) The calculated positions are stored as a point cloud, with each point containing $\mathrm{X}, \mathrm{Y}$ and $\mathrm{Z}$ coordinates and additional attribute information such as GPS time, intensity, echo-width, and scanning angle. These are individual points in space that have no physical relationship to each other, but due to their density can be used to define features such as ground or buildings $[27,28]$. These features are defined by point cloud processing. Arguably, the most important step is the automatic ground point classification, where each point is classified either as ground (terrain) or non-ground (off-terrain) [11,15]. This is a probabilistic rather than a deterministic process, and any classification includes false positives (ground points classified as non-ground) and false negatives (non-ground points classified as ground) [33].

(2.2) Next, non-ground points are further classified by object type. While any object type classification is based directly on the results of ground point classification, there are various approaches to this step in archaeological practice. Approaches range from ignoring this step altogether (only DEM is used) to making it the primary goal of the analysis (nonground objects are the focus). Because of this diversity, this step is considered a separate step. Of archaeological interest are primarily non-ground archaeological features (for example castle ruins) [11], but also buildings and sometimes vegetation. Points classified as vegetation are rarely directly relevant for archaeological interpretation (but see [34]), but low vegetation density can be used both for planning ground assessment (areas with dense low vegetation can only be surveyed during the season of dormant vegetation, while other 
areas may be accessible all year round) and as one of the proxies for the accuracy of the final model (for example non-ground features are more likely to be lost in areas with dense low vegetation, regardless of the density of ground points).

(2.3) Currently successful automatic filtering methods are ideally up to $96.29 \%$ accurate [35], but within archaeological sites under unfavorable conditions the accuracy can be as low as $37 \%$ [11]. Features at the cliff edges and non-ground archaeological features in dense vegetation are particularly prone to errors (see bellow). In such cases, a manual reclassification of the point cloud is essential. It is carried out by viewing the vertical profile sections of the point cloud and thus identifying and reclassifying incorrectly classified points. The process consists of a series of discrete microdecisions made by the operator, who relies heavily on the experience and knowledge of local geomorphology, vegetation, and archaeological features. Sometimes, a field survey in selected small areas is required to provide sufficient context data [20]. The whole process is time-consuming and is therefore typically limited to focus areas of high archaeological importance $[20,28]$.

(2.4) Based on the classified point cloud, a digital raster model is interpolated. Interpolation is a process in which a grid of defined cell size is effectively draped over the point data. This means that the cells are derived from the original data and do not consist of the actual data points $[27,36]$. The archaeology-specific digital raster model combines a digital terrain model (DTM, also known as digital elevation model, DEM, in US-centric usage [15,29]) with off-terrain archaeological features [15] and, for contextual information, modern buildings, e.g., [11,13,37,38]. Such an "archaeological digital elevation model" [15] has been termed the digital feature model (DFM) [39].

(2.5) Enhanced visualizations are then computed from the DFM. One of the most important distinctions separating archaeology-specific from general mapping workflows is that instead of one visualization (usually analytical hillshading) several enhanced visualizations are created, for example, sky view factor, openness and difference from mean elevation [40,41]. Often, a fusion of several visualizations is used, e.g., [42-44] (see bellow).

\subsection{Archaeological Interpretation (3.1-3.5)}

Only at this stage does the archaeological interpretation begin (but see $[13,21]$ where visualization is considered part of interpretation).

(3.1) Airborne LiDAR data become particularly valuable in combination with other relevant data sources $[21,45]$, both pertaining to the past and present (for example, archaeological geodatabase, aerial photographs, historical maps, geological maps, and soil maps). The reason is that airborne LiDAR, just as aerial photography [46], indiscriminately records information derived from many causes and spanning many millennia. Additional data sources are in aid to isolate the archaeological evidence. Therefore, as a first step of archaeological interpretation, all available relevant data are integrated in a GIS environment [21]. The activity can be as simple as connecting a Web Map Service or as complex as discovering, retrieving, scanning, georeferencing, and vectorizing historical maps.

(3.2) Interpretative mapping is a desk-based archaeological interpretation in which archaeological sites and features are identified, interpreted, and mapped. It is based on the analysis of the enhanced visualizations and additional data sources engaged in a GIS environment. The method draws from the interpretation of aerial photography, e.g., [46], but there are key differences: the LiDAR data are born geocoded, the observeroriented biases [47] are negligible, and the features are recognized solely by their surface morphology [21]. As a consequence, both the workflow and the results are specific to airborne LiDAR data.

The aim of interpretative mapping is to create a geodatabase containing archaeological features mapped as points, polylines, or polygons with associated feature-specific metadata. The geometry type depends on the type of project. For example, in a regional analysis that focuses on mapping previously unknown sites, an entire hillfort is mapped as a point (e.g., [48]). A similar hillfort, if it is a focus of an intra-site analysis, is mapped using a series of polygons and polylines (e.g., [49]). At a medium scale, for example, a cairnfield can be 
mapped either as points for ground assessment and dissemination [43] or as polygons for a detailed morphological study. This is also reflected in the effort required to map a set area. A very rough estimate ranges from $19 \mathrm{~km}^{2} /$ person/day for a regional project (as reported by Ralph Hesse), $1 \mathrm{~km}^{2} /$ person/day for a medium scale project (experience in the MALiAp project) or two days $\left(0.02 \mathrm{~km}^{2} /\right.$ person/day) for an in-depth analysis of a complex site (e.g., experience in [49]). In addition to the archaeological features, the so-called negative zones must also be mapped [46]. Those are areas where no archaeological information can be obtained with airborne LiDAR. The most common examples are built-up areas, areas under very intensive modern agriculture, and areas with insufficient data quality.

The interpretative mapping is a highly specialized activity carried out with a combination of perception and comprehension $[4,13,27]$. This has two important consequences. Firstly, highly skilled experts for archaeological LiDAR, who are also familiar with the archaeological landscape under investigation, are critical for the success. A vital skill, for example, is the ability to recognize an archaeological feature while filtering out features due to modern agricultural practices, geology, and data processing artefacts [27]. Secondly, this process is as subjective as any other archaeological interpretation. Therefore, the level of confidence in each mapped feature will vary, and to maintain scientific integrity, it must be recorded [42].

(3.3) Ground assessment is a field-based activity that builds upon the interpretative mapping. Its objective is to further decipher, interpret, and understand the archaeological features. Differences in terminology - ground validation [29], ground-truthing [50], LiDAR guided survey [21], and field survey [27]—help to explain the existing differences in the understanding of this activity in archaeological practice. Activities in the field draw heavily from the archaeo-topographical survey, which comprises close observation and interpretation of the ground surface, direct measurement of all significant features, detailed analysis of the relationships between features and the production of a plan that illustrates the interpretation arrived at [51]. In fact, the entire airborne LiDAR workflow is sometimes understood as just an additional method for the archaeo-topographical survey [52-54]. However, in our view, access to airborne LiDAR data fundamentally redefines the survey by (i) splitting the activities into desk-based interpretative mapping and field-based ground assessment [13,21], (ii) enabling unsurpassed metrical accuracy [27], (iii) providing the widest possible landscape context $[13,27]$, and, perhaps most importantly, (iv) enabling a precisely targeted and planned fieldwork that can be carried out very efficiently [21]. The latter two are often the key to archaeological interpretation in forests where field-based observation is limited. Therefore, we understand the ground assessment as a LiDARspecific archaeological method.

The key objectives in the field are to assess features on the ground against the LiDARderived information and to search for dating evidence. Landscape study, after all, is desperate for approximate dates that can be provided by small-scale excavation at crucial points or intersections [46]. Valuable secondary information can also be recorded, ranging from learning about the landscape context to interviewing knowledgeable locals. As such, ground assessment is by far the most time-consuming activity per given area in the entire workflow. Therefore, most often only selected areas and/or features are targeted for ground assessment.

There is an essential aspect of ground assessment that must be carried over from the archaeo-topographical survey if it is to retain its interpretive rigor. This is to understand the undeniable positive effect that a set of bodily practices and sensibilities gained during the field work has on the archaeological interpretation [55]. It stems from "dense, extensive and experiential engagement with its subject landscape that few other archaeological methods could equal" [53]. Since very similar engagement is achieved during the interpretative mapping, ground assessment is at its best when it is intertwined with interpretative mapping in a hermeneutic approach with a feedback loop [21]. In other words, for the best results, personnel involved in interpretative mapping should also be involved in ground assessment and vice versa, e.g., [42]. 
(3.4) The final step in interpretation is the integrated multi-scale 'deep' interpretation, which aims to deepen the understanding of the archaeological features in their landscape environment. In a typical application, environmental factors (for example distance to water, soil quality, exposure to wind, visibility) are combined with human agency and individuals by addressing the cognitive space $[13,56]$.

(3.5) The automated (or semi-automated) mapping of archaeological features provides a means for rapid data extraction. The two main approaches used today are pixel-based classification and object-oriented image analysis [57]. An emerging trend is the shift from rule-based object detection to machine learning methods [58]. Regardless of the tools used, the method aims to complement interpretative mapping, especially in situations where so much data is available that it becomes difficult to map everything manually [59-61].

It is hoped that automated mapping will eventually become a standard part of the workflow, but currently that is not the case. A typical automated mapping project still requires more time and effort than an interpretative mapping, even if the number of targeted features is in the thousands, and is therefore undertaken as a separate endeavor. The other main obstacle is that targeted archaeological features not only need to be known, but also need to be very precisely defined in advance (either defined as a rule or "learned" with a machine learning process). Therefore, only archaeological features that have an invariable morphology and are abundant can be targeted. Until now, the focus has been limited to a handful: mound structures (burial mounds [59,62-68], charcoal kilns [69,70], and shell-rings [71]), pit structures (hunting system [72]; ore extraction pits [72,73], and bomb craters [74]), and linear sunken structures (paths [75,76], ditches [77], and mining shafts [73]). There is a recent trend of targeting complex features [78] and multiple feature types (multi-class archaeological object detection [77,79-84]), but complex archaeological landscapes imbedded in a complex terrain with ample anthropogenic influence remains challenging $[80,81]$.

Against this background, the above definition of automated mapping must be adjusted: automated mapping provides a means for rapid mapping of selected categories of previously known archaeological features. In other words, while archaeology is in the process of gaining a powerful mapping tool for known features, archaeological interpretation will remain in the domain of experts for the foreseeable future.

\subsection{Dissemination and Archiving (4.1-4.3)}

The dissemination and archiving of airborne LiDAR data is an important, but until now largely neglected part of the workflow.

(4.1) Since airborne LiDAR datasets are often very large, data management strategies are important. Tiling is an effective way of organizing the data during processing and interpretation [28], as are other standard GIS practices, e.g., [85].

(4.2) The dissemination of LiDAR data and, more importantly, its archaeology-specific derivates received surprisingly little attention in archaeology. Despite the early adoption of webGIS (e.g., reported by [28]) the most ubiquitous form of dissemination remains publication in journals. It is expected that in the near future more suitable forms-fusing the recognition of journal articles with the advantages of webGIS—will prevail [86].

(4.3) Spatial data archiving issues are currently widely debated inside and outside of archaeology, but as of yet there are no generally accepted practices $[17,87]$. The starting premise is that all data, including raw and point-cloud data, should be archived in a persistent repository to make the whole process of processing repeatable (Figure 1). The preparation of LiDAR datasets for archiving requires the choice between different file formats $[28,88]$. It has become the standard practice in the industry to store data in a compressed open source LAZ format that complies with ASPRS specification 1.4 [36]. Metadata standards for LiDAR data are still evolving and there are no archaeology-specific standards that are widely accepted, but guidance is provided by Opitz [28]. However, archaeologists often do not have copyright of the data, which can be an additional problem for archiving [27]. In addition, ethical and regulatory aspects must be considered both in 
dissemination and archiving [1,2]. At the very least, however, the results of interpretative mapping should be archived according to accepted standards for GIS data [89].

\subsection{Workflow Implementation}

The workflow described is not necessarily a linear task that is performed once by a single team. In fact, the opposite is more often the case and it can also be more productive [86]. An example of good practice is that the raw data acquisition and processing (1.1-1.5) is performed by a team of airborne LiDAR specialists, e.g., [90]. Another team of archaeologists specialized in airborne LiDAR data will process the point cloud, derive the products (2.1-2.5) and conclude with interpretative mapping (3.1-3.2) [43]. Each team will document, disseminate, and archive their respective steps. If the off-the-shelf data is used, several years may pass between the two projects. From this point on, different archaeologists may work with the information provided by interpretative mapping, either as part of the daily tasks of heritage management or as part of the teaching process or with a focused research purpose. Other approaches are also possible (Figure 1).

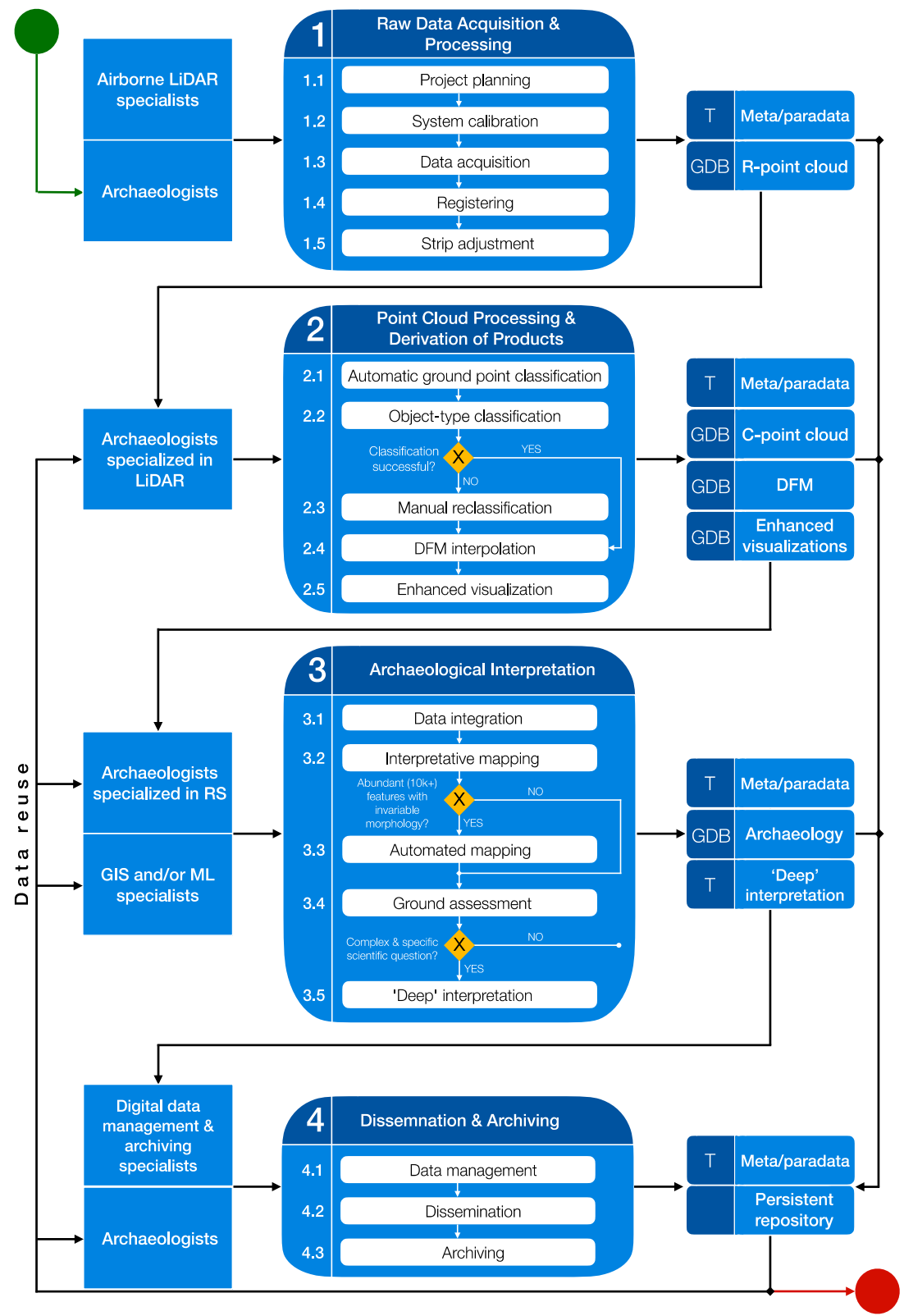

Figure 1. Context data-flow diagram (DFD1) of archaeology-specific airborne LiDAR data processing. Symbols for external entity, process, data flow and data store are based on Gane and Sarson's notations [91], but with additional notations for data store types: GDB—geodatabase, $\mathrm{T}$ - (textual) descriptive data store. 


\section{Results: Documenting the Research Process}

\subsection{Project Documentation}

At first it is important to highlight that the creation of documentation must be an ongoing process throughout the lifecycle of the project. It should be actively pursued from the outset of a project as it is often difficult to create retrospectively [89].

Information about the project background is part of every archaeological project, but is often overlooked in archaeological practice. It ranges from generally applicable information at the project level, such as project name, location, and duration, to specific metadata at the record or file level, such as what file formats are present in the archive and what applications were used to create them. The potential re-use of digital data makes it particularly important that this information is clearly reported. Furthermore, project documentation includes methodology, site or landscape narrative, and the archaeological context. In many cases, it may simply be appropriate to include a bibliographic reference. Finally, there may be additional documentation that contains information that is missing in the metadata records, supports them or is more detailed than the metadata records. An example of this is a digital copy of the project design [89].

\subsection{Raw Data Acquisition and Processing (1.1-1.5)}

There are rich metadata and paradata on the raw data acquisition and processing (Table 3). Broadly speaking, they fall into four categories: data availability, data potential, exploited data potential, and data potential available for point cloud processing. The first category is metadata, which reports on the availability of the data; for example, if the data is owned by a public body that has a good record on data archiving, it is likely that the data is and will be available for archaeology. However, not all data types are equally important for the archaeology-specific workflow and, perhaps more importantly, not all types are comprehensible to non-specialists.

Table 3. An example of raw data acquisition and processing metadata $(\mathrm{M})$ and paradata $(\mathrm{P})$ recorded for a selected block B35 of the Airborne Laser Scanning of Slovenia project [92,93]. Importance (for archaeology-specific workflow): o-average; +- high; ++ very high.

\begin{tabular}{|c|c|c|c|c|c|}
\hline Step & Importance & $\mathbf{M} / \mathbf{P}$ & Type & Example & Category \\
\hline \multirow[t]{7}{*}{$\begin{array}{l}1.1 \text { Project } \\
\text { planning }\end{array}$} & ++ & M & Title & $\begin{array}{l}\text { Lasersko skeniranje } \\
\text { Slovenije }\end{array}$ & Data availability \\
\hline & + & M & Brief description & Countrywide scanning & Data potential \\
\hline & + & $\mathrm{P}$ & Purpose & $\begin{array}{l}\text { General purpose, flood } \\
\text { protection management }\end{array}$ & Data potential \\
\hline & + & M & Platform & Fixed wing aircraft & Data potential \\
\hline & ++ & $\mathrm{P}$ & Date of flight(s) & $\begin{array}{c}\text { between } 14 \text { March } 2014 \text { and } \\
2 \text { April } 2015\end{array}$ & Data potential \\
\hline & o & $\mathrm{P}$ & Operator & Flycom d.o.o. & $\begin{array}{c}\text { Data availability, data } \\
\text { potential }\end{array}$ \\
\hline & ++ & M & Custodian & GURS & Data availability \\
\hline \multirow{10}{*}{$\begin{array}{l}1.2 \text { System } \\
\text { calibration }\end{array}$} & + & $\mathrm{P}$ & Scanner type & Full-waweform & Data potential \\
\hline & o & M & $\begin{array}{c}\text { Instruments (laser } \\
\text { scanner/INS/GNSS) }\end{array}$ & $\begin{array}{c}\text { RIEGL LMS-Q780/IGI } \\
\text { Aerocontrol Mark II.E } 256 \\
\text { Hz/GNSS: Novatel OEMV-3 }\end{array}$ & Data potential \\
\hline & o & M & $\begin{array}{l}\text { Pulse repetition rate (PRR) } \\
{[\mathrm{kHz}]}\end{array}$ & $\mathrm{N} / \mathrm{A}$ & Data potential \\
\hline & + & M & Wavelength & $\mathrm{N} / \mathrm{A}$ & Data potential \\
\hline & + & M & Max. scanning angle & $\pm 30^{\circ} 1$ & Data potential \\
\hline & $\mathrm{o}$ & M & Scan lines per second & $\mathrm{N} / \mathrm{A}$ & Data potential \\
\hline & ++ & M & additional sensors & None & Data potential \\
\hline & $\mathrm{o}$ & M & Max. scanning angle error & $0.25 \mathrm{mrad}$ & Data potential \\
\hline & o & M & INS angle accuracy & $\begin{array}{l}\text { roll } / \text { pitch } 0.004^{\circ} \text {; heading } \\
0.01^{\circ} \text {; position } 0.05 \mathrm{~m}\end{array}$ & Data potential \\
\hline & $\mathrm{o}$ & M & $\begin{array}{c}\text { INS-GNSS-laser } \\
\text { synchronisation error }\end{array}$ & $0.005 \mathrm{~ms}$ & Data potential \\
\hline
\end{tabular}


Table 3. Cont.

\begin{tabular}{|c|c|c|c|c|c|}
\hline Step & Importance & $\mathbf{M} / \mathbf{P}$ & Type & Example & Category \\
\hline \multirow[t]{9}{*}{$\begin{array}{l}\text { (1.3) Data } \\
\text { acquisition }\end{array}$} & o & M & $\begin{array}{l}\text { Altitude above ground level } \\
\text { (AGL) }\end{array}$ & $1200-1400 \mathrm{~m}$ & Data potential \\
\hline & $\mathrm{o}$ & $\mathrm{M}$ & Average speed & $165 \mathrm{kts} / 105 \mathrm{~ms}$ & Data potential \\
\hline & o & M & Flight strip overlap & $\mathrm{N} / \mathrm{A}(<5 \%)$ & Data potential \\
\hline & $\mathrm{o}$ & M & Swath width & $865 \mathrm{~m}$ & Data potential \\
\hline & ++ & M & Footprint diameter $[\mathrm{m}]$ & $\mathrm{N} / \mathrm{A}$ & Data potential \\
\hline & ++ & M & $\begin{array}{l}\text { Average laser pulse density } \\
\text { per } \mathrm{m} 2\end{array}$ & 5 & Data potential \\
\hline & ++ & M & $\mathrm{N} / \mathrm{E} / \mathrm{H}$ accuracy (precision) & $\pm 0.02 / 0.02 / 0.025$ & Data potential \\
\hline & ++ & M & Vegetation state & Dormant & Data potential \\
\hline & o & M & No. of flight strips & 28 & Data availability \\
\hline \multirow[t]{8}{*}{$\begin{array}{l}(1.4) \\
\text { Registering }\end{array}$} & o & $\mathrm{P}$ & $\begin{array}{l}\text { Flight trajectory calculation } \\
\quad \text { (software/method) }\end{array}$ & $\begin{array}{c}\text { GrafNav } \\
\text { (Waypoint-Novatel) } \\
\text { v8.50/DGPS }\end{array}$ & Exploited data potential \\
\hline & $\mathrm{o}$ & $\mathrm{P}$ & $\begin{array}{c}\text { GNSS and IMU merging } \\
\text { (software) }\end{array}$ & AeroOffice (IGI) v5.1f & Exploited data potential \\
\hline & $\mathrm{o}$ & $\mathrm{P}$ & $\begin{array}{c}\text { Raw data analysis } \\
\text { (software) }\end{array}$ & $\begin{array}{c}\text { RiPROCESS v1.5.9: } \\
\text { RiANALYZE v6.0.2 (RIEGL) }\end{array}$ & Exploited data potential \\
\hline & $\mathrm{o}$ & $\mathrm{P}$ & $\begin{array}{l}\text { Merging of raw data with } \\
\text { flight trajectory }\end{array}$ & $\begin{array}{l}\text { RiPROCESS v1.5.9: } \\
\text { RiWORLD v4.5.8 (RIEGL) }\end{array}$ & Exploited data potential \\
\hline & + & $\mathrm{P}$ & $\begin{array}{c}\text { Full-Waveform Processing } \\
\text { and Filtering }\end{array}$ & $\mathrm{N} / \mathrm{A}$ & Exploited data potential \\
\hline & $\mathrm{o}$ & $\mathrm{P}$ & LAS export (software) & RiPROCESS (RIEGL) v1.5.9 & $\begin{array}{l}\text { Data potential available for } \\
\text { point cloud processing }\end{array}$ \\
\hline & ++ & M & LAS format & 1.2 & $\begin{array}{l}\text { Data potential available for } \\
\text { point cloud processing }\end{array}$ \\
\hline & ++ & M & Coordinate system & D96/TM & $\begin{array}{l}\text { Data potential available for } \\
\text { point cloud processing }\end{array}$ \\
\hline \multirow[t]{2}{*}{$\begin{array}{l}\text { (1.5) Strip } \\
\text { adjustment }\end{array}$} & + & $\mathrm{P}$ & Strip adjustment (yes/no) & Yes & Exploited data potential \\
\hline & o & $\mathrm{P}$ & $\begin{array}{l}\text { Strip adjustment } \\
\text { (software/method) }\end{array}$ & $\begin{array}{c}\text { TerraMatch (TerraScan)/line } \\
\text { matching }\end{array}$ & Exploited data potential \\
\hline
\end{tabular}

${ }^{1}$ Reported value, actual value is $33^{\circ}$.

Therefore, in archaeological practice, most of these metadata and paradata must only be reported where the raw data acquisition and processing is published. For example, when off-the-shelf dataset is reused for archaeological purposes, it suffices to reference the already published metadata and paradata (usually available in technical reports). However, some types of metadata are of high interest for archaeology-specific point cloud processing and should be always included. These are: date of flight, data ownership, additional sensors, footprint diameter, N/E/H accuracy, vegetation state, LAS format, and coordinate system.

\subsection{Point Cloud Processing and Derivation of Products (2.1-2.5)}

Since the point cloud data processing bears the most importance to the archaeologyspecific outcomes [15], the metadata and paradata for this project phase are of key importance.

Automatic ground point classification (2.1), arguably the most important step of the workflow, is relatively easy to document. Key information is the paradata on the filter (specific software implementation of an algorithm) and filter settings; for the latter, the detailed explanation in [11] can be consulted. Similar goes for the object-type classification (2.2), DFM interpolation (2.4), and enhanced visualization (2.5) (Table 4). 
Table 4. An example of point cloud processing and derivation of products paradata for Figures 2-4.

\begin{tabular}{|c|c|c|c|}
\hline Step & Importance & Type & Example \\
\hline \multirow[t]{3}{*}{$\begin{array}{l}\text { (2.1) Automatic ground point } \\
\text { classification }\end{array}$} & ++ & Software & LAStools $^{1}$ Rapidlasso $\mathrm{GmbH}$ \\
\hline & ++ & Filter & lasground_new \\
\hline & ++ & Settings & $\begin{array}{l}\text { st: } 5 \text {; g: /; off: } 0.05 ; \mathrm{s}+: 1.0 ; \mathrm{s}-: 1.0 \text {; b: no; terrain } \\
\text { type: wilderness; pre-processing: ultra fine }{ }^{2}\end{array}$ \\
\hline \multirow[t]{6}{*}{ (2.2) Object-type classification } & + & Software & LAStools ${ }^{1}$, Rapidlasso $\mathrm{GmbH}$ \\
\hline & + & Filter & lasheight \\
\hline & + & Settings & $\begin{array}{c}\text { classify between: } 0.5 \text { and } 2 \text { as 3; classify between: } 2 \\
\text { and } 5 \text { as } 4 \text {; classify above: } 5 \text { as } 5\end{array}$ \\
\hline & + & Software & LAStools ${ }^{1}$, Rapidlasso $\mathrm{GmbH}$ \\
\hline & + & Filter & lasclassify \\
\hline & o & Settings & $\begin{array}{l}\text { building planarity: } 0.1 \text {; forest ruggedness: } 0.4 ; \\
\text { ground offset: } 1.8\end{array}$ \\
\hline \multirow[t]{4}{*}{ (2.3) Manual reclassification } & + & Targeted area & Within the known site of castle ruins \\
\hline & + & Targeted features & Standing archaeological features (type 3) \\
\hline & + & Software & Global Mapper ${ }^{\circledR}$ 21.1.x, Bluemarblegeo \\
\hline & ++ & Change-detection map & See Figure $2 d$ \\
\hline \multirow[t]{3}{*}{ (2.4) DFM interpolation } & + & Software & Surfer 17.1.x, Goldensoftware ${ }^{\circledR}$ \\
\hline & + & Filter & Kriging \\
\hline & + & Settings & $\begin{array}{l}\text { Kriging type: point; Drift: none; No. sectors: } 4 \text {; Max. } \\
\text { all sectors: 64; Max. each sector: } 16 \text {; Min. all sectors: } \\
\text { 8; Radius 1: 20; Radius 2: } 20 \text {; cell size: } 0.25 \mathrm{~m} \text {. }\end{array}$ \\
\hline \multirow[t]{9}{*}{ (2.5) Enhanced visualization } & ++ & Software & RVT 2.2.1, ZRC SAZU \\
\hline & ++ & Filter & Sky view factor \\
\hline & o & Settings & $\begin{array}{c}\text { No. search directions: } 32 \text {; Search radius: } 10 \text {; Remove } \\
\text { noise: no. }\end{array}$ \\
\hline & o & Software & RVT 2.2.1. ZRC SAZU \\
\hline & o & Filter & Visualization for archaeological topography (VAT) \\
\hline & o & Settings & setting: steep. \\
\hline & $\mathrm{o}$ & Software & WhiteboxTools 1.4.0., University of Guelph's GHRG \\
\hline & o & Filter & DiffFromMeanElev \\
\hline & $\mathrm{o}$ & Settings & x dimension: 10; y dimension: 10 \\
\hline
\end{tabular}

${ }^{1}$ No versioning supplied, software downloaded 15 June $2020 .{ }^{2}$ For details on settings see [11].

Manual reclassification (2.3), on the other hand, consists of informed but subjective discrete microdecisions by the operator. Paradata includes the software used and the procedures employed and metadata reports on which areas and/or feature types were targeted and why. However, this falls short of informing on the impact of manual reclassification on the end product. To this end, we propose a change-detection map of the Z-coded difference between DFM before and after manual reclassification. For clarity, the change-detection map should be visualized with classified values (Figure $2 \mathrm{~d}$ ). 


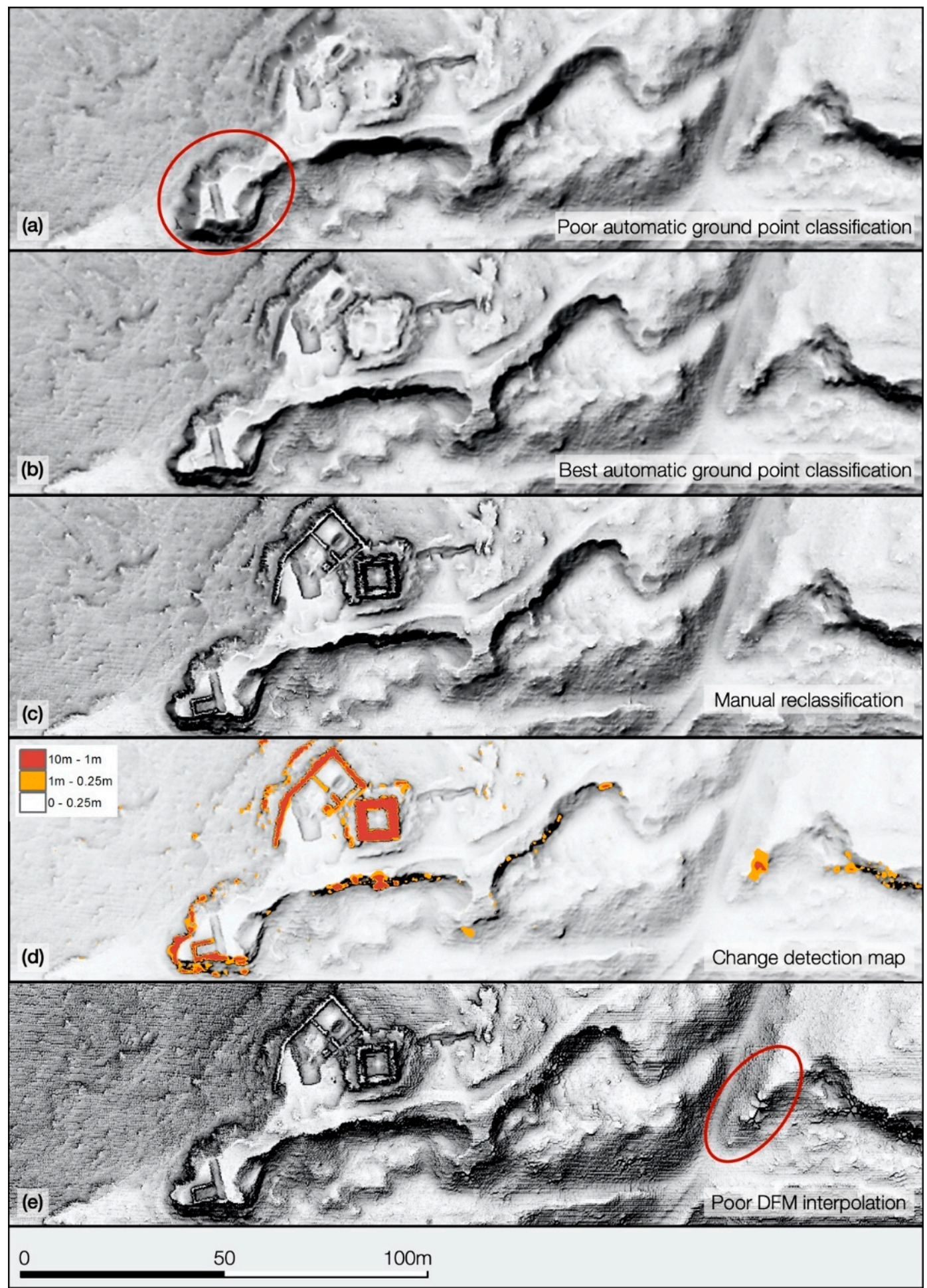

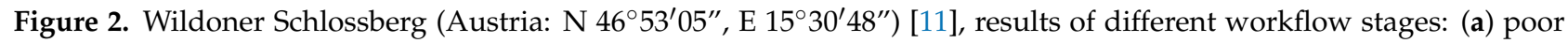
automatic ground point classification (MCC-Lidar, see [11], Appendix A for details); (b) best automatic ground point classification; (c) manual reclassification of (b); (d) change-detection map of the manual reclassification (calculated as $|(\mathbf{c}),(\mathbf{b})|)(\mathbf{e})$ same process as (b), but with nearest neighbor DFM interpolation. All images: VAT visualization, $0.25 \mathrm{~m}$ DFM (see Table 4 for details). 


\subsection{Archaeological Interpretation (3.1-3.5)}

\subsubsection{Interpretative Mapping (3.2)}

The main focus in this section is the documentation of interpretative mapping, which is rarely made explicit in archaeological studies [21]. However, we argue that a generally accepted metadata schema for interpretative mapping of airborne LiDAR-derived data is a prerequisite for its recognition as an independent scientific knowledge production process.

As mentioned above, interpretative mapping involves the creation of a geodatabase containing geocoded mapping of features (points, polylines, polygons) and rich featurelevel data [27]. Grammer et al. proposed to record geometric properties, description, interpretation metadata, interpretation rationale, interpretation results, and uncertainties [21]. Through archaeological practice, we have independently developed a similar schema, but with more emphasis on uncertainty and a more structured approach to interpretation [94-97]. It consists of thirteen categories, which are described below and should be regarded as a minimal amount of feature-specific information to be recorded (Table 5).

Table 5. Attribute data produced during the interpretative mapping of the Knežak area [43]. Category: M-metadata; $\mathrm{P}$-paradata; D-data.

\begin{tabular}{|c|c|c|c|c|}
\hline Name & Data Type & Example & Data Source & Category \\
\hline ID & Sequential integer number & 10,001 & Automatic & M \\
\hline Feature Type & Controlled vocabulary & Cairn & Operator & $\mathrm{D}$ \\
\hline Feature Confidence & Integer number $0-3$ & 3 & Operator & $\mathrm{D}$ \\
\hline Chronology & Controlled vocabulary & Iron Age & Operator & $\mathrm{D}$ \\
\hline $\begin{array}{l}\text { Chronology } \\
\text { Confidence }\end{array}$ & Integer number $0-3$ & 2 & Operator & $\mathrm{D}$ \\
\hline Interpretation & Free text & $\begin{array}{l}\text { Cairn, a part of the } \\
\text { Knežak hillfort } \\
\text { cairnfield. }\end{array}$ & Operator & $\mathrm{D}$ \\
\hline Source & $\begin{array}{l}\text { Controlled vocabulary, multiple entries } \\
\text { possible }\end{array}$ & SVF & Operator & $\mathrm{P}$ \\
\hline Visibility & Integer number $1-2$ & 2 & Operator & $\mathrm{P}$ \\
\hline Low vegetation density & Integer number $1-3$ & 2 & Automatic & $\mathrm{D}$ \\
\hline Other & Free text & $\mathrm{N} / \mathrm{A}$ & Operator & $\mathrm{D}$ \\
\hline Author & Controlled vocabulary & E.L. & Automatic & M \\
\hline Date & Date & 10 September 2016 & Automatic & M \\
\hline Geometric properties & Area $\left(\mathrm{m}^{2}\right)$, length $(\mathrm{m})$ & $13.1 \mathrm{~m}^{2}$ & Automatic & $\mathrm{D}$ \\
\hline Coordinates & $\mathrm{XYZ}$ coordinates & $\begin{array}{c}440,929.17,53,033.93 \\
674.75\end{array}$ & Automatic & $\mathrm{D}$ \\
\hline
\end{tabular}

ID is a consecutive identification number that is automatically assigned for each mapped feature. It is used throughout the entire workflow, including ground assessment.

Feature type provides a short description of the archeological feature, for example, ditch, mound, cairn, earthwork, quarry, etc. The list of feature types mapped with airborne LiDAR data is, if not short, at least manageable. However, there is as yet no "global" controlled vocabulary or list of feature types. Therefore, each project has to create its own.

Feature confidence refers to the confidence in the feature interpretation. For example, a barely visible cairn in the midst of the cairnfield can be interpreted with the highest degree of confidence, whereas an excellently visible feature that was previously unknown to the area can only be interpreted with a lower degree of confidence. Four categories of confidence are used: ' 0 ' none (feature type is unknown), ' 1 ' low (feature is detected but interpretation is questionable, e.g., an isolated and indistinct mound structure could be a cairn), ' 2 ' medium (the feature is clearly visible and there are analogies to the confirmed interpretation in the area, but the morphology is not distinct; e.g., a cairn in a cairnfield can on a rare occasion turn out to be a burial mound), and ' 3 ' high (the feature is clearly visible and has a distinct form, e.g., a quarry; alternatively, there is direct evidence to support the interpretation). 
Chronology refers to the archaeological dating of the feature. For example, we use Prehistory (general), Bronze Age, Iron Age, Roman Period, Late Antiquity, Early Medieval. It is decided on previous archeological knowledge, analogies and the contextualization of the features. The most common examples of the latter are the stratigraphy (feature A cuts feature B) and the archaeological context (for example, a path connecting two Iron Age hillforts and bypassing an Iron Age burial mound is likely of the Iron Age date).

Chronology confidence refers to four categories: ' 0 ' none (chronology is unknown), ' 1 ' low (e.g., analogies in adjacent areas are known), ' 2 ' medium (indirect dating evidence, e.g., nearby analogous features have been dated with direct evidence), and ' 3 ' high (direct field-based dating evidence). Interpretation is a text field in which interpretation is briefly discussed together with its criteria and reasons. If contextualization was possible for the documented features, they were interpreted (e.g., Iron Age hillfort, quarry, Roman villa rustica, Roman Road, path of unknown date). For the vast majority of features, this field will include a reference. For example, 600 cairns belonging to a single cairnfield will be interpreted only once.

Source of visualization: A number of visualization techniques are available, each of which provides different information in different environments. This has a direct impact on interpretative mapping [41] and thus the type of visualization used for mapping must be documented. If multiple visualizations are needed to map the feature in its entirety, all values are recorded. If the RVT tool [44] is used, its naming conventions can be used as a controlled vocabulary. Visibility describes how well the feature is visible, which is a function of contrast in the source visualization [21]. In practice, we have resorted to the choice between only two categories, ' 1 ' poor or ' 2 ' good.

Low vegetation density is the key element, along with the ground point density, that determines the quality of DFM. It is calculated from point cloud data and its density is described as ' 1 ' negligible, ' 2 ' medium (introduces occasional and/or moderate noise into DFM) or ' 3 ' high (introduces constant and/or significant noise into DFM). The description is not a direct measurement of point density, as it depends on several variables: laser pulse density, season of data acquisition, and type of local vegetation.

Author refers to the person who performed the lidar interpretation.

Date refers to the date when the feature was first recorded.Other data may vary between projects, and more fields may be needed. An example is an identification code from the existing sites and monuments database where the feature has already been recorded.

Geometric properties are derivatives of the mapped features. Area or length are recorded, but other properties such as relative height (easily calculated from the local relief model or difference from mean elevation) can be added.

Coordinates of each feature's centroid are given.

In addition to the above feature-level data, the project-level metadata and paradata for interpretative mapping must also be reported. This includes, but is not limited to, the description and explanation of: controlled vocabularies, the survey area, the survey type (scale), the choice of feature geometry, and the coordinate system. These are provided as descriptive documentation within a technical report or scientific publication.

\subsubsection{Ground Assessment (3.3)}

The ground assessment feature-specific documentation builds upon the interpretative mapping geodatabase. Through archaeological practice, we have developed the schema described below (Table 6). The schema should be regarded as a minimal amount of featurespecific information to be recorded. 
Table 6. Attribute data produced during the ground assessment of the Knežak area [43]. Category: M-metadata; $\mathrm{P}-$ paradata; D-data.

\begin{tabular}{|c|c|c|c|c|}
\hline Name & Data Type & Example & Data Source & Category \\
\hline ID & $\begin{array}{c}\text { Sequential integer } \\
\text { number }\end{array}$ & 10,001 & Automatic & M \\
\hline Feature Type & Controlled vocabulary & Cairn & Operator & $\mathrm{D}$ \\
\hline Feature Confidence & Integer number $0-3$ & 3 & Operator & $\mathrm{D}$ \\
\hline Chronology & Controlled vocabulary & Iron Age & Operator & $\mathrm{D}$ \\
\hline $\begin{array}{l}\text { Chronology } \\
\text { Confidence }\end{array}$ & Integer number 0-3 & 2 & Operator & $\mathrm{D}$ \\
\hline Interpretation & Free text & $\begin{array}{c}\text { Cairn, a part of the Knežak hillfort } \\
\text { cairnfield. }\end{array}$ & Operator & $\mathrm{D}$ \\
\hline Visibility (field) & Integer number 1-3 & 2 & Operator & $\mathrm{P}$ \\
\hline Vegetation & Controlled vocabulary & Mature deciduous forest & Operator & $\mathrm{D}$ \\
\hline Field notes & Free text & $\begin{array}{l}\text { Cairn is overgrown with grass that is } \\
\text { lower than in its surroundings, which } \\
\text { indicates stony interior. }\end{array}$ & Operator & $\mathrm{D}$ \\
\hline $\begin{array}{l}\text { Photographic } \\
\text { documentation }\end{array}$ & & Photography & Operator & $\mathrm{D}$ \\
\hline Author & Controlled vocabulary & B. ̌̌. & Automatic & M \\
\hline Date & Date & 15 January 2017 & Automatic & M \\
\hline
\end{tabular}

The fields related to feature type and confidence, chronology and chronology confidence, and interpretation are reused from interpretative mapping. However, to achieve the best results, the fields are filled out again during the ground assessment. Any differences between the desk-based and field-based data are investigated. In the final report, though, these fields should be consolidated.

Visibility in the field during ground assessment may differ significantly from that of LiDAR visualizations. Two main reasons for the discrepancy are vegetation and feature type (slight positive or negative bulges are well visible in some visualizations, but hardly visible in the field). Visibility in the field is described as ' 1 ' poor (the feature is hardly visible), ' 2 ' medium (the feature is partially obscured), and ' 3 ' good (the feature is visible in its entirety).

The vegetation and its conditions are described using a controlled vocabulary specific to the project. Details, such as vegetation marks, are described in the field notes.

Field notes are a standard part of any archaeo-topographic survey, describing the observations on the feature. Specific to ground assessment is that morphology and geometric properties, which often make up the bulk of the notes of an archaeo-topographic survey, are described only in terms of differences from airborne LiDAR-derived data.

Photographic documentation of a field survey is a well-documented subject, e.g., [98,99]. However, in certain aspects it is specific to the ground assessment. The key difference is that photography does not have to depict the landscape context or the geometric properties of the feature. Both are better represented in LiDAR visualizations. The photographer should therefore focus on those properties that are only visible from the ground, for example, by using low angle views to document the silhouette of a cairn in detail.

Author and date refer to the ground assessment.

As mentioned above, the interpretative mapping and ground assessment geodatabases will be consolidated for final dissemination.

In addition to the feature-level data, the project-level metadata and paradata for ground assessment must also be provided. The good practice of documenting archaeotopographic surveys can be followed, e.g., [53,98-100]. This includes, but is not limited to, the description and explanation of: personnel, field methods, choice of survey targets, weather and other conditions, but also basic notes on the field observations. These are provided as descriptive documentation within a technical report or a scientific publication. 


\subsubsection{Other $(3.1,3.4,3.5)$}

All other steps of interpretation have in common that they are not documented according to a given schema, but in free text form.

Data integration is essentially a GIS task and should be documented according to the existing standards [89]. Furthermore, each data source used should be properly referenced and described.

'Deep' interpretation process cannot be described with a set of predefined types of metadata and paradata, as this is a far too complex and too diverse an undertaking. It is usually provided in the form of descriptive documentation within the relevant section of a scientific publication, e.g., [56,101].

Automated mapping is still, as mentioned, almost always a separate project. In addition, the methodology is currently developing rapidly. In fact, most publications at this point focus on methodology and thus on the documentation of data processing, e.g., $[77,79-83]$. This means that a standardization of the documentation is not possible for the time being.

\subsection{Dissemination and Archiving (4.1-4.3)}

Dissemination and especially archiving are essential aspects of the entire workflow. In particular the archiving of archaeology-specific airborne LiDAR data in particular is an area that urgently requires metadata standardization. However, such an endeavor goes beyond the scope of this article.

\section{Discussion and Conclusions}

This paper aimed to achieve two objectives. Firstly, to provide an up-to-date and comprehensive review of the archaeology-specific workflow for airborne LiDAR data acquisition, processing, and interpretation. Secondly, it aimed to demonstrate a good practice of documenting this process. In doing so, we have shown that, from the perspective of knowledge production, each step of the workflow involves assumptions and decisions that are either made by the operator or embedded in the software $[16,27,28]$. Thus, the whole process is subject to a continuous stream of discrete archaeology-specific (or nonarchaeology-specific) decisions.

However, not all steps of the workflow are equally archaeology-specific and therefore not all of them have to be performed exclusively by archaeologists. For projects that acquire custom data, the acquisition (1.1-1.3) should be done by a domain expert who works with the archaeological end-user from the beginning $[15,29,30]$. For example, poor project planning can lead to insufficient laser pulse density [29] (Figure 3), and even a seemingly minute setting of beam divergence can have a significant impact on the visibility of archaeological features [29]. Optimum results can only be achieved through close cooperation between the airborne LiDAR specialist and an archaeologist with sufficient background knowledge.

Raw data processing (1.4-1.5) is best performed by a domain expert, since the standard operating software is often supplied with the scanners (for example, RIEGEL software RiPROCESS must be used for data acquired with RIEGEL laser scanner) and requires very specialized knowledge $[27,28]$. Under certain circumstances, however, archaeologyspecific processing can be advantageous, so that the involvement of archaeologists can be beneficial. For example, the removal of points with high echo width and hierarchic robust interpolation when processing full wave-form raw data can improve the filtering of low vegetation [16]. Another example is the use of additional data acquired by the LiDAR sensors, such as the reflectance data [102,103]. 


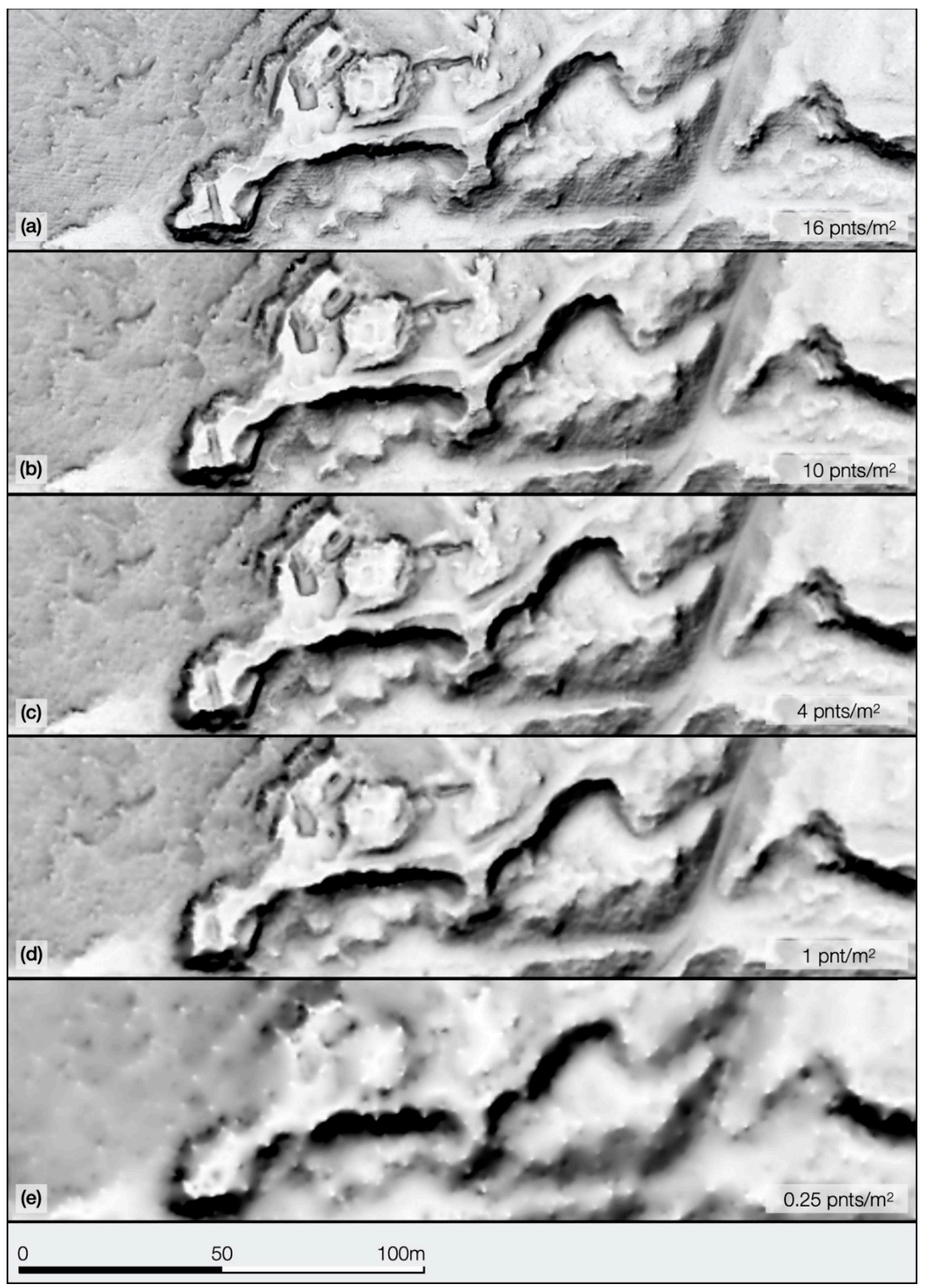

Figure 3. Wildoner Schlossberg (Austria: N 46 $53^{\prime} 05^{\prime \prime}$, E $15^{\circ} 30^{\prime} 48^{\prime \prime}$ ) [11], modelling the effect of insufficient data pulse density and subsequently point cloud density. VAT visualization, $0.25 \mathrm{~m} \mathrm{DFM}$, processes according to the Table 4 . The only difference is point density: (a)—full data, 16 pnts $/ \mathrm{m}^{2} ;(\mathbf{b})-10 \mathrm{pnts} / \mathrm{m}^{2} ;$ (c) $-4 \mathrm{pnts} / \mathrm{m}^{2} ;(\mathbf{d})-1 \mathrm{pnt} / \mathrm{m}^{2} ;(\mathbf{e})-0.25 \mathrm{pnt} / \mathrm{m}^{2}$. In this case archaeological features can be interpreted on (a), (b) and partially in (c).

In more recent archaeological practice, though, data is mainly obtained as a point cloud sourced from large-scale general-purpose mapping projects. In such cases, archaeologists are end-users who have had no influence on raw data acquisition and processing. Fortunately, however, it is the processing of point cloud data (2.1-2.3) and the derivation 
of products (2.4-2.5) that are most specific to archaeology. Most important is the ground point filtering [11,15], where non-archaeology-specific choices can erase entire sections of a site. If manual reclassification is omitted, it will invariably have a considerable negative impact on the retention of the standing features. Especially for data with low pulse density, the correct choice of interpolation is also important ([95]; compare Figure 2e to Figure 2c). Thus, the importance of using archaeology-specific visualizations [41] cannot be overstated (Figure 4). Therefore, only if archaeology-specific processing is applied can low density data be successfully repurposed for archaeology $[95,104,105]$.

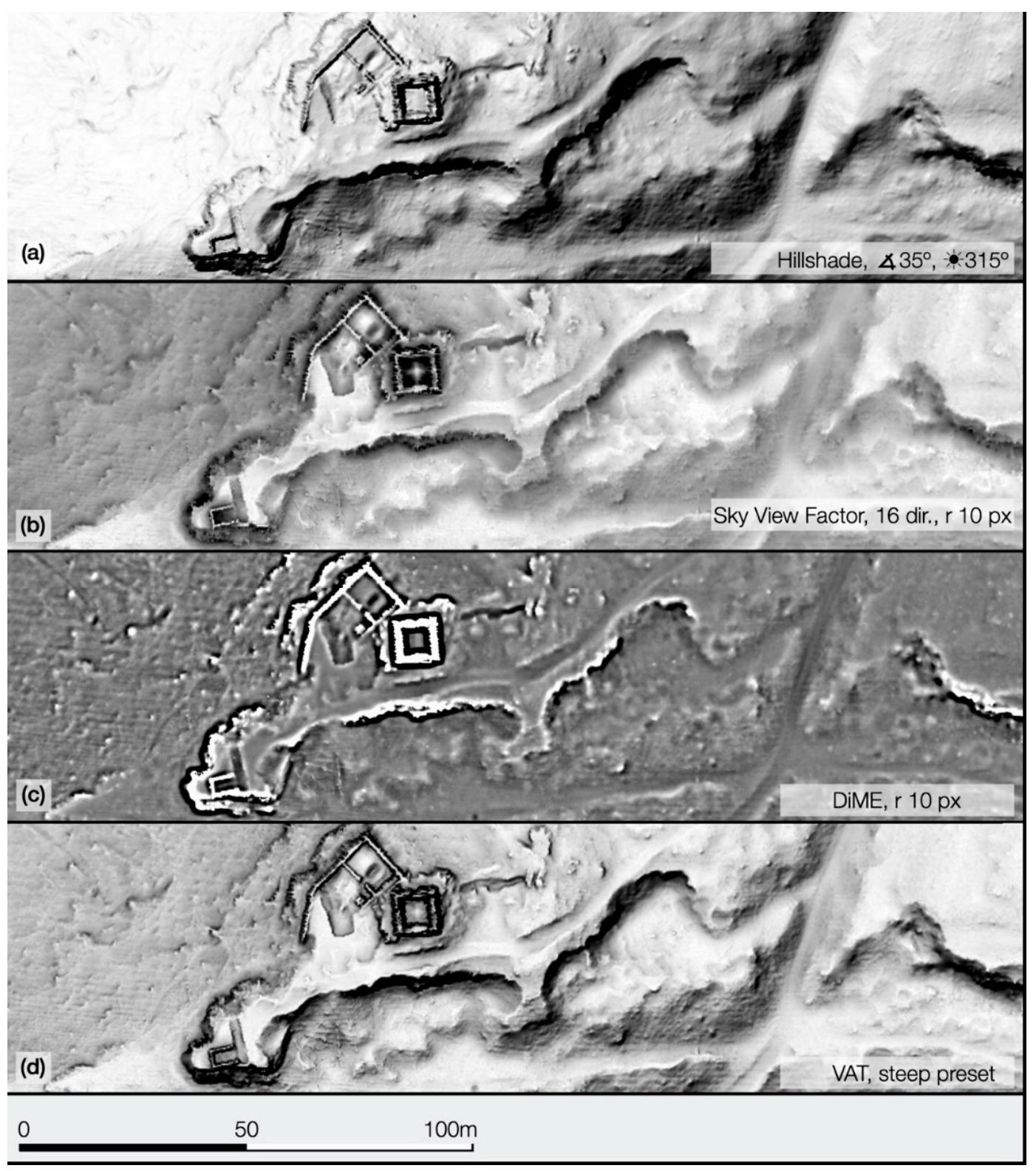

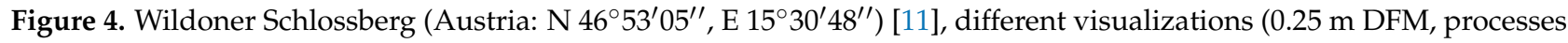
according to the Table 4). The only difference is visualization type: (a)—hillshade; (b) sky view factor; (c)—difference from mean elevation; (d) - visualiszation for archaeological topography.

The archaeological interpretation (3.1-3.5) must be carried out by archaeologists with sufficient training in GIS and remote sensing, and with sufficient knowledge of the specific archaeological landscape. However, dissemination, except for publications, and archiving (4.1-4.3) should be carried out by the domain experts in consortium with archaeologists. 
Unfortunately, such a symbiosis between experts and archaeologists is rare in archaeological practice. As mentioned in the introduction, the steps from data acquisition to product derivation (1.1-2.5) are accepted by many archaeologists as a black box process and the visualization of DFMs as "hard data". To exacerbate the issue, archaeological interpretation is rarely properly documented and, to our knowledge, is never published with complete metadata and paradata. The latter is admittedly very difficult in the existing landscape of scientific publishing where the concepts of executable scientific publications [106] and data papers [107] are in their infancy and the airborne LiDAR in archaeology is yet to bridge the gap between the publication of research data and scientific articles [86].

This can only change gradually and only when all the above-mentioned interconnected moving parts fall into place. This paper presents two important steps towards this goal. Firstly, it provides the most comprehensive description of the archaeology-specific workflow for airborne LiDAR data processing to date. Its novelty and significance lies in the fact that the existing comprehensive studies are outdated and the newer ones focus on selected aspects of the workflow. Secondly, a good practice example for the documentation of the knowledge production process based on this workflow is presented. The paper is of interest to archaeologists who are either specialists in the field and need an up-to-date overview or who, as non-specialists, are looking for a general understanding of the data they use. The paper will also appeal to a broader readership of non-archaeologists who use airborne LiDAR data in a similar way to archaeologists, for example, for visual inspection or as input for machine learning.

Author Contributions: Conceptualization, E.L.; methodology, B.Š.; formal analysis, E.L.; writingoriginal draft preparation, B.S.; writing-review and editing, B.Š.; data processing, E.L.; project administration, B.Š.; funding acquisition, B.Š. and E.L. All authors have read and agreed to the published version of the manuscript.

Funding: This research was funded by ARRS SLOVENIAN RESEARCH AGENCY, grant numbers N6-0132 and P6-0064, and FWF AUSTRIAN SCIENCE FOUND grant number 13992.

Institutional Review Board Statement: Not applicable.

Informed Consent Statement: Not applicable.

Data Availability Statement: Not applicable.

Acknowledgments: The authors want to thank to the reviewers for the contribution to the final version of the article.

Conflicts of Interest: The authors declare no conflict of interest.

\section{References}

1. Cohen, A.; Klassen, S.; Evans, D. Ethics in Archaeological Lidar. J. Comput. Appl. Archaeol. 2020, 3, 76-91. [CrossRef]

2. Chase, A.S.Z.; Chase, D.; Chase, A. Ethics, New Colonialism, and Lidar Data: A Decade of Lidar in Maya Archaeology. J. Comput. Appl. Archaeol. 2020, 3, 51-62. [CrossRef]

3. Crutchley, S. Light Detection and Ranging (lidar) in the Witham Valley, Lincolnshire: An Assessment of New Remote Sensing Techniques. Archaeol. Prospect. 2006, 13, 251-257. [CrossRef]

4. Challis, K.; Carey, C.; Kincey, M.; Howard, A.J. Assessing the preservation potential of temperate, lowland alluvial sediments using airborne lidar intensity. J. Archaeol. Sci. 2011, 38, 301-311. [CrossRef]

5. Inomata, T.; Triadan, D.; Vázquez López, V.A.; Fernandez-Diaz, J.C.; Omori, T.; Méndez Bauer, M.B.; García Hernández, M.; Beach, T.; Cagnato, C.; Aoyama, K. Monumental architecture at Aguada Fénix and the rise of Maya civilization. Nature 2020, 582, 530-533. [CrossRef] [PubMed]

6. Stanton, T.W.; Ardren, T.; Barth, N.C.; Fernandez-Diaz, J.C.; Rohrer, P.; Meyer, D.; Miller, S.J.; Magnoni, A.; Pérez, M. “Structure” density, area, and volume as complementary tools to understand Maya Settlement: An analysis of lidar data along the great road between Coba and Yaxuna. J. Archaeol. Sci. Rep. 2020, 29, 102178. [CrossRef]

7. Evans, D. Airborne laser scanning as a method for exploring long-term socio-ecological dynamics in Cambodia. J. Archaeol. Sci. 2016, 74, 164-175. [CrossRef]

8. Rom, J.; Haas, F.; Stark, M.; Dremel, F.; Becht, M.; Kopetzky, K.; Schwall, C.; Wimmer, M.; Pfeifer, N.; Mardini, M.; et al. Between Land and Sea: An Airborne LiDAR Field Survey to Detect Ancient Sites in the Chekka Region/Lebanon Using Spatial Analyses. Open Archaeol. 2020, 6, 248-268. [CrossRef] 
9. Gheyle, W.; Stichelbaut, B.; Saey, T.; Note, N.; Van den Berghe, H.; Van Eetvelde, V.; Van Meirvenne, M.; Bourgeois, J. Scratching the surface of war. Airborne laser scans of the Great War conflict landscape in Flanders (Belgium). Appl. Geogr. 2018, 90, 55-68. [CrossRef]

10. Gillings, M.; Hacıgüzeller, P.; Lock, G. (Eds.) Re-Mapping Archaeology; Routledge: London, UK, 2018.

11. Štular, B.; Lozić, E. Comparison of Filters for Archaeology-Specific Ground Extraction from Airborne LiDAR Point Clouds. Remote Sens. 2020, 12, 3025. [CrossRef]

12. Doneus, M. Die hinterlassene Landschaft. Prospektion und Interpretation in der Landschaftsarchäologie; Verlag der Österreichischen Akademie der Wissenschaften: Vienna, Austria, 2013.

13. Doneus, M.; Kühtreiber, T. Interpreting Archaeological Topography. Airborne Laser Scanning, 3D Data and Ground Observation. In Interpreting Archaeological Topography. Airborne Laser Scanning, 3D Data and Ground Observation; Opitz, R.S., Cowley, D.C., Eds.; Oxbow Books: Oxford, UK, 2013; pp. 33-50.

14. Opitz, R.S.; Cowley, D.C. Interpreting archaeological topography: Lasers, 3D data, observation, visualisation and applications. In Interpreting Archaeological Topography. Airborne Laser Scanning, 3D Data and Ground Observation; Opitz, R.S., Cowley, D.C., Eds.; Oxbow Books: Oxford, UK, 2013; pp. 1-13. ISBN 978-1-84217-516-3.

15. Doneus, M.; Mandlburger, G.; Doneus, N. Archaeological Ground Point Filtering of Airborne Laser Scan Derived Point-Clouds in a Difficult Mediterranean Environment. J. Comput. Appl. Archaeol. 2020, 3, 92-108. [CrossRef]

16. Doneus, M.; Briese, C. Airborne Laser Scanning in forested areas-potential and limitations of an archaeological prospection technique. In Remote Sensing for Archaeological Heritage Management. Proceedings of the 11th EAC Heritage Management Symposium, Reykjavik, Iceland, 25-27 March 2010; EAC Occasional Paper; Cowley, D.C., Ed.; Europae Archaeologia Consilium (EAC): Brussel, Belgium, 2011; pp. 59-76. ISBN 978-963-9911-20-8.

17. McKeague, P.; Corns, A.; Larsson, Å.; Moreau, A.; Posluschny, A.; Daele, K.V.; Evans, T. One Archaeology: A Manifesto for the Systematic and Effective Use of Mapped Data from Archaeological Fieldwork and Research. Information 2020, 11, 222. [CrossRef]

18. Hammersley, M. The issue of quality in qualitative research. Int. J. Res. Method Educ. 2007, 30, 287-305. [CrossRef]

19. Friedhoff, S.; Meier zu Verl, C.; Pietsch, C.; Meyer, C.V.; Liebig, S. Social Research Data. Documentation, Management, and Technical Implementation within the SFB 882; University of Bielefeld, Faculty of Sociology: Bielefeld, Germany, 2013; pp. 1-3.

20. Štular, B.; Lozić, E. Primernost podatkov projekta Lasersko skeniranje Slovenije za arheološko interpretacijo: Metoda in študijski primer (The Suitability of Laser Scanning of Slovenia Data for Archaeological Interpretation: Method and a Case Study). In Digitalni Podatki; Ciglič, R., Geršič, M., Perko, D., Zorn, M., Eds.; Geografski Inštitut Antona Melika ZRC SAZU: Ljubljana, Slovenia, 2016; pp. 157-166. ISBN 978-961-254-929-9.

21. Grammer, B.; Draganits, E.; Gretscher, M.; Muss, U. LiDAR-guided Archaeological Survey of a Mediterranean Landscape: Lessons from the Ancient Greek Polis of Kolophon (Ionia, Western Anatolia). Archaeol. Prospect. 2017, 24, 311-333. [CrossRef]

22. Denard, H. Implementing Best Practice in Cultural Heritage Visualisation: The London Charter. In Good Practice in Archaeological Diagnostics. Non-Invasive Survey of Complex Archaeological Sites; Corsi, C., Slapšak, B., Vermeulen, F., Eds.; Springer: Berlin/Heidelberg, Germany, 2013; pp. 255-268. ISBN 978-3-319-01784-6.

23. Apollonio, F.I.; Giovannini, E.C. A paradata documentation methodology for the Uncertainty Visualization in digital reconstruction of CH artifacts. SCIRES-IT Sci. Res. Inf. Technol. 2015, 5. [CrossRef]

24. Richards-Rissetto, H. What can GIS + 3D mean for landscape archaeology? J. Archaeol. Sci. 2017, 84, 10-21. [CrossRef]

25. Wilkinson, M.D.; Dumontier, M.; Aalbersberg, I.J.J.; Appleton, G.; Axton, M.; Baak, A.; Blomberg, N.; Boiten, J.-W.; da Silva Santos, L.B.; Bourne, P.E. The FAIR Guiding Principles for scientific data management and stewardship. Sci. Data 2016, 3. [CrossRef]

26. Gregory, K.; Groth, P.; Scharnhorst, A.; Wyatt, S. Lost or Found? Discovering Data Needed for Research. Harv. Data Sci. Rev. 2020, 2. [CrossRef]

27. Crutchley, S.; Crow, P. The Light Fantastic: Using Airborne Laser Scanning in Archaeological Survey; English Heritage: Swindon, UK, 2010; pp. 17-27.

28. Opitz, R.S. An overview of airborne and terrestrial laser scanning in archaeology. In Interpreting Archaeological Topography. Airborne Laser Scanning, 3D Data and Ground Observation; Opitz, R.S., Cowley, D.C., Eds.; Oxbow Books: Oxford, UK, 2013; pp. 13-31. ISBN 978-1-84217-516-3.

29. Fernandez-Diaz, J.C.; Carter, W.E.; Shrestha, R.L.; Glennie, C.L. Now You See It ... Now You Don't: Understanding Airborne Mapping LiDAR Collection and Data Product Generation for Archaeological Research in Mesoamerica. Remote Sens. 2014, 6, 9951-10001. [CrossRef]

30. Doneus, M.; Briese, C. Full-waveform airborne laser scanning as a tool for archaeological reconnaissance. In From Space to Place: 2nd International Conference on Remote Sensing in Archaeology: Proceedings of the 2nd International Workshop, CNR, Rome, Italy, 4-7 December 2006; Campana, S., Forte, M., Eds.; British Archaeological Reports (BAR) International Series; Archaeopress: Oxford, UK, 2006; pp. 99-105.

31. Wehr, A. LiDAR Systems and Calibration. In Topographic Laser Ranging and Scanning: Principles and Processing; Shan, J., Toth, C.K., Eds.; CRC Press: Boca Raton, FL, USA; Taylor \& Francis Group: London, UK; Taylor \& Francis Group: New York, NY, USA, 2018; pp. 159-200. ISBN 978-1-4987-7227-3.

32. Toth, C.K.; Koppanyi, Z. Strip Adjustment. In Topographic Laser Ranging and Scanning: Principles and Processing; Shan, J., Toth, C.K., Eds.; CRC Press: Boca Raton, FL, USA; Taylor \& Francis Group: London, UK; Taylor \& Francis Group: New York, NY, USA, 2018; pp. 259-290. ISBN 978-1-4987-7227-3. 
33. Sithole, G.; Vosselman, G. Experimental comparison of filter algorithms for bare-Earth extraction from airborne laser scanning point clouds. ISPRS J. Photogramm. Remote Sens. 2004, 59, 85-101. [CrossRef]

34. Hightower, J.; Butterfield, A.; Weishampel, J. Quantifying Ancient Maya Land Use Legacy Effects on Contemporary Rainforest Canopy Structure. Remote Sens. 2014, 6, 10716-10732. [CrossRef]

35. Buján, S.; Cordero, M.; Miranda, D. Hybrid Overlap Filter for LiDAR Point Clouds Using Free Software. Remote Sens. 2020, 12, 1051. [CrossRef]

36. Dong, P.; Chen, Q. LiDAR Remote Sensing and Applications; Taylor \& Francis Series in Remote Sensing Applications; CRC Press: Boca Raton, FL, USA, 2018; pp. 46-61. ISBN 978-1-4822-4301-7.

37. Johnson, K.M.; Ouimet, W.B. An observational and theoretical framework for interpreting the landscape palimpsest through airborne LiDAR. Appl. Geogr. 2018, 91, 32-44. [CrossRef]

38. Rutkiewicz, P.; Malik, I.; Wistuba, M.; Osika, A. High concentration of charcoal hearth remains as legacy of historical ferrous metallurgy in southern Poland. Quat. Int. 2019, 512, 133-143. [CrossRef]

39. Pingel, T.J.; Clarke, K.; Ford, A. Bonemapping: A LiDAR Processing and Visualization Technique in Support of Archaeology Under the Canopy. Cartogr. Geogr. Inf. Sci. 2015, 42, 18-26. [CrossRef]

40. Štular, B.; Kokalj, Ž.; Oštir, K.; Nuninger, L. Visualization of lidar-derived relief models for detection of archaeological features. J. Archaeol. Sci. 2012, 39, 3354-3360. [CrossRef]

41. Kokalj, Ž.; Hesse, R. Prostor, Kraj, Čas. In Airborne Laser Scanning Raster Data Visualization: A Guide to Good Practice; Založba ZRC: Ljubljana, Slovenia, 2017; ISBN 978-961-254-984-8.

42. Banaszek, Ł.; Cowley, D.C.; Middleton, M. Towards National Archaeological Mapping. Assessing Source Data and MethodologyA Case Study from Scotland. Geosciences 2018, 8, 272. [CrossRef]

43. Laharnar, B.; Lozić, E.; Štular, B. A structured Iron Age landscape in the hinterland of Knežak, Slovenia. In Rural Settlement: Relating Buildings, Landscape, and People in the European Iron Age; Cowley, D.C., Fernández-Götz, M., Romankiewicz, T., Wendling, H., Eds.; Sidestone Press: Leiden, The Netherlands, 2019; pp. 263-272. ISBN 978-90-8890-820-0.

44. Kokalj, Z.; Somrak, M. Why Not a Single Image? Combining Visualizations to Facilitate Fieldwork and On-Screen Mapping. Remote Sens. 2019, 11, 747. [CrossRef]

45. Davis, D.S.; DiNapoli, R.J.; Sanger, M.C.; Lipo, C.P. The Integration of Lidar and Legacy Datasets Provides Improved Explanations for the Spatial Patterning of Shell Rings in the American Southeast. Adv. Archaeol. Pract. 2020, 8, 361-375. [CrossRef]

46. Musson, C.; Palmer, R.; Campana, S. Flights into the Past. Aerial Photography, Photo Interpretation and Mapping for Archaeology; Occasional Publication; Aerial Archaeology Research Group: York, UK, 2013; ISBN 978-3-00-044479-1.

47. Verhoeven, G.; Sevara, C. Trying to Break New Ground in Aerial Archaeology. Remote Sens. 2016, 8, 918. [CrossRef]

48. Bofinger, J.; Hesse, R. As far as the laser can reach ... Laminar analysis of LiDAR detected structures as a powerful instrument for archaeological heritage management in Baden-Württemberg, Germany. In Remote Sensing for Archaeological Heritage Management. Proceedings of the 11th EAC Heritage Management Symposium, Reykjavik, Iceland, 25-27 March 2010; Cowley, D.C., Ed.; EAC Occasional Paper; Europae Archaeologia Consilium (EAC): Brussel, Belgium, 2011; pp. 162-171. ISBN 978-963-9911-20-8.

49. Laharnar, B.; Štular, B.; Mlinar, M. Gradič above Kobarid-A late republican fortified emporium? = Gradič nad Kobaridom, poznorepublikanski utrjeni emporij? In Evidence of the Roman Army in Slovenia = Sledovi Rimske Vojske na Slovenskem; Istenič, J., Laharnar, B., Horvat, J., Eds.; Katalogi in monografije/Catalogi et monographiae; Narodni Muzej Slovenije: Ljubljana, Slovenia, 2015; pp. 243-256. ISBN 978-961-6169-97-4.

50. Thompson, A.E. Detecting Classic Maya Settlements with Lidar-Derived Relief Visualizations. Remote Sens. 2020, $12,2838$. [CrossRef]

51. Bowden, M.; McOmish, D. A British Tradition? Mapping the Archaeological Landscape. Landscapes 2011, 12, 20-40. [CrossRef]

52. Stewart Ainsworth, A.O.; Went, D. Remotely acquired, nor remotely sensed: Using lidar as a field survey tool. In Interpreting Archaeological Topography. Airborne Laser Scanning, 3D Data and Ground Observation; Opitz, R.S., Cowley, D.C., Eds.; Oxbow Books: Oxford, UK, 2013; pp. 206-222. ISBN 978-1-84217-516-3.

53. Fradley, M. The eye of the beholder: Experience, encounter and objectivity in archaeo-topographical survey. In Re-Mapping Archaeology; Gillings, M., Hacıgüzeller, P., Lock, G., Eds.; Routledge: London, UK, 2018; pp. 97-166. ISBN 978-1-351-26771-7.

54. Verhagen, P. Site Discovery and Evaluation Through Minimal Interventions: Core Sampling, Test Pits and Trial Trenches. In Good Practice in Archaeological Diagnostics. Non-Invasive Survey of Complex Archaeological Sites; Corsi, C., Slapšak, B., Vermeulen, F., Eds.; Springer: New York, NY, USA, 2013; pp. 209-226. ISBN 978-3-319-01784-6.

55. Johnson, M. Landscape studies: The future of the field. In Landscape Archaeology between Art and Science. From a Multi- to an Interdisciplinary Approach; Kluiving, S.J., Guttmann-Bond, E.B., Eds.; Amsterdam University Press: Amsterdam, The Netherlands, 2012; pp. 515-525. ISBN 978-90-8964-418-3.

56. Štular, B. The use of lidar-derived relief models in archaeological topography. The Kobarid region (Slovenia) case study (Uporaba modelov reliefa pridobljenih z lidarskim snemanjem v arheološki topografiji. Študijski primer Kobariške). Arheol. Vestn. Acta Archaeol. 2011, 62, 393-432.

57. Sevara, C.; Pregesbauer, M. Archaeological feature classification: An object oriented approach. S. East. Eur. J. Earth Obs. Geomat. 2014, 3, 139-143.

58. Lambers, K.; der Vaart, W.V.; Bourgeois, Q. Integrating Remote Sensing, Machine Learning, and Citizen Science in Dutch Archaeological Prospection. Remote Sens. 2019, 11, 794. [CrossRef] 
59. Sevara, C.; Pregesbauer, M.; Doneus, M.; Verhoeven, G.; Trinks, I. Pixel versus object-A comparison of strategies for the semi-automated mapping of archaeological features using airborne laser scanning data. J. Archaeol. Sci. Rep. 2016, 5, 485-498. [CrossRef]

60. Davis, D.S. Object-based image analysis: A review of developments and future directions of automated feature detection in landscape archaeology. Archaeol. Prospect. 2018, 26, 155-163. [CrossRef]

61. Albrecht, C.M.; Fisher, C.; Freitag, M.; Hamann, H.F.; Pankanti, S.; Pezzutti, F.; Rossi, F. Learning and Recognizing Archeological Features from LiDAR Data. Proc. IEEE 2019. [CrossRef]

62. Boer, A.D. Using pattern recognition to search LIDAR data for archeological sites. In The World Is in Your Eyes. CAA2005. Computer Applications and Quantitative Methods in Archaeology, Proceedings of the 33rd Conference, Tomar, March 2005; Figueiredo, A., Leite Velho, G., Eds.; CAA Portugal: Tomar, Portugal, 2005; pp. 245-254.

63. Riley, M.A.; Artz, J.A. LiDAR Surveyor: A Tool for Automated Archaeological Feature Extraction from Light Detection and Ranging (LiDAR) Elevation Data; Office of the State Archaeologist, The University of Iowa: Iowa City, IA, USA, 2012.

64. Trier, Ø.D.; Zortea, M.; Tonning, C. Automatic detection of mound structures in airborne laser scanning data. J. Archaeol. Sci. Rep. 2015, 2, 69-79. [CrossRef]

65. Freeland, T.; Heung, B.; Burley, D.V.; Clark, G.; Knudby, A. Automated feature extraction for prospection and analysis of monumental earthworks from aerial LiDAR in the Kingdom of Tonga. J. Archaeol. Sci. 2016, 69, 64-74. [CrossRef]

66. Cerrillo-Cuenca, E. An approach to the automatic surveying of prehistoric barrows through LiDAR. Quat. Int. 2017, 435, 135-145. [CrossRef]

67. Guyot, A.; Hubert-Moy, L.; Lorho, T. Detecting Neolithic Burial Mounds from LiDAR-Derived Elevation Data Using a Multi-Scale Approach and Machine Learning Techniques. Remote Sens. 2018, 10, 225. [CrossRef]

68. Niculita, M. Geomorphometric Methods for Burial Mound Recognition and Extraction from High Resolution LiDAR DEMs. Sensors 2020, 20, 1192. [CrossRef]

69. Schneider, A.; Takla, M.; Nicolay, A.; Raab, A.; Raab, T. A Template-matching Approach Combining Morphometric Variables for Automated Mapping of Charcoal Kiln Sites. Archaeol. Prospect. 2014, 22, 45-62. [CrossRef]

70. Witharana, C.; Ouimet, W.B.; Johnson, K.M. Using LiDAR and GEOBIA for automated extraction of eighteenth-late nineteenth century relict charcoal hearths in southern New England. GIScience Remote Sens. 2018, 55, 183-204. [CrossRef]

71. Davis, D.S.; Lipo, C.P.; Sanger, M.C. A comparison of automated object extraction methods for mound and shell-ring identification in coastal South Carolina. J. Archaeol. Sci. Rep. 2019, 23, 166-177. [CrossRef]

72. Trier, Ø.D.; Pilø, L.H. Automatic Detection of Pit Structures in Airborne Laser Scanning Data. Archaeol. Prospect. 2012, $19,103-121$. [CrossRef]

73. Gallwey, J.; Yeomans, C.; Tonkins, M.; Coggan, J.; Vogt, D.; Eyre, M. Using Deep Learning and Hough Transformations to Infer Mineralised Veins from LIDAR Data Over Historic Mining Areas. ISPRS Int. Arch. Photogramm. Remote Sens. Spat. Inf. Sci. 2020, 1561-1568. [CrossRef]

74. Magnini, L.; Bettineschi, C.; Guio, A.D. Object-based Shell Craters Classification from LiDAR-derived Sky-view Factor. Archaeol. Prospect. 2016, 24, 211-223. [CrossRef]

75. Vletter, W.F. (Semi) automatic extraction from Airborne Laser Scan data of roads and paths in forested areas. In Second International Conference on Remote Sensing and Geoinformation of the Environment (RSCy2014); Hadjimitsis, D.G., Themistocleous, K., Michaelides, S., Papadavid, G., Eds.; Proceedings of SPIE; SPIE: Washington, DC, USA, 2014; Volume 9229, pp. 92291D-1-92291D-11.

76. Sherba, J.; Blesius, L.; Davis, J. Object-Based Classification of Abandoned Logging Roads under Heavy Canopy Using LiDAR. Remote Sens. 2014, 6, 4043-4060. [CrossRef]

77. De Matos-Machado, R.; Toumazet, J.-P.; Bergès, J.-C.; Amat, J.-P.; Arnaud-Fassetta, G.; Bétard, F.; Bilodeau, C.; Hupy, J.P.; Jacquemot, S. War landform mapping and classification on the Verdun battlefield (France) using airborne LiDAR and multivariate analysis. Earth Surf. Process. Landf. 2019, 44. [CrossRef]

78. Toumazet, J.-P.; Vautier, F.; Roussel, E.; Dousteyssier, B. Automatic detection of complex archaeological grazing structures using airborne laser scanning data. J. Archaeol. Sci. Rep. 2017, 12, 569-579. [CrossRef]

79. Trier, Ø.D.; Salberg, A.-B.; Pilø, L.H.; Tonning, C.; Johansen, H.M.; Aarsten, D. Semi-automatic mapping of cultural heritage from airborne laser scanning using deep learning. Geophys. Res. Abstr. 2016, 18, 159-186.

80. Trier, Ø.D.; Cowley, D.C.; Waldeland, A.U. Using deep neural networks on airborne laser scanning data: Results from a case study of semi-automatic mapping of archaeological topography on Arran, Scotland. Archaeol. Prospect. 2018, 26, 165-175. [CrossRef]

81. Meyer, M.; Pfeffer, I.; Jürgens, C. Automated Detection of Field Monuments in Digital Terrain Models of Westphalia Using OBIA. Geosciences 2019, 9, 109. [CrossRef]

82. der Vaart, W.B.V.; Lambers, K. Learning to Look at LiDAR: The Use of R-CNN in the Automated Detection of Archaeological Objects in LiDAR Data from the Netherlands. J. Comput. Appl. Archaeol. 2019, 2, 31-40. [CrossRef]

83. Trier, Ø.D.; Reksten, J.H.; Løseth, K. Automated mapping of cultural heritage in Norway from airborne lidar data using faster R-CNN. Int. J. Appl. Earth Obs. Geoinf. 2021, 95, 102241. [CrossRef]

84. Bundzel, M.; Jaščur, M.; Kováč, M.; Lieskovský, T.; Sinčák, P.; Tkáčik, T. Semantic Segmentation of Airborne LiDAR Data in Maya Archaeology. Remote Sens. 2020, 12, 3685. [CrossRef]

85. Tian, B. GIS Technology Applications in Environmental and Earth Sciences; Taylor and Francis, Ltd.: Boca Raton, FL, USA, 2017; ISBN 978-1-4987-7604-2. 
86. Štular, B. Scientific Dissemination of Archaeological Interpretation of Airborne LiDAR-derived Data. A Manifesto. In Critical Archaeology in the Digital Age; Garstky, K., Ed.; The Cotsen Institute of Archaeology Press: Los Angeles, CA, USA, 2021; pp. 185-204.

87. McKeague, P.; vant Veer, R.; Huvila, I.; Moreau, A.; Verhagen, P.; Bernard, L.; Cooper, A.; Green, C.; van Manen, N. Mapping Our Heritage: Towards a Sustainable Future for Digital Spatial Information and Technologies in European Archaeological Heritage Management. J. Comput. Appl. Archaeol. 2019, 2, 89-104. [CrossRef]

88. Shaw, R.; Corns, A. Archiving Archaeological Spatial Data: Standards and Metadata. In Making History Interactive. Computer Applications and Quantitative Methods in Archaeology (CAA), Proceedings of the 37th International Conference, Williamsburg, Virginia, United States of America, 22-26 March 2009; Frischer, B., Koller, D., Eds.; BAR International Series; Archaeopress: Williamsburg, NY, USA, 2009; Volume S2079, pp. 22-26. ISBN 978-1-4073-0556-1.

89. Gillings, M.; Wise, A.; Evans, T.; Halls, P.J.; Niven, K. GIS Guide to Good Practice; ADS Guides to Good Practice; Archaeology Data Service. 2011. Available online: https://guides.archaeologydataservice.ac.uk/g2gp/Gis_Toc (accessed on 27 November 2020).

90. Triglav Čekada, M.; Bric, V. Končan je projekt laserskega skeniranj Slovenije. Geod. Vestn. 2015, 59, 586-592.

91. Gane, C.; Sarson, T. Structured Systems Analysis; Prentice-Hall: Englewood Cliffs, NJ, USA, 1979.

92. Pegan Žvokelj, P.; Bric, V.; Triglav Čekada, M. Lasersko skeniranje Slovenije (Laser Scanning in Slovenia). Geod. Vestn. 2014, 58, 349-351.

93. Mivšek, E. Izvedba Laserskega Skeniranja Slovenije. Blok 35-Tehnično Poročilo o Izdelavi Izdelkov; Geodetski Inštitut Slovenije: Ljubljana, Slovenia, 2015.

94. Lozić, E. Analiza Lidarskih Podatkov za Lokaciji Veliki in Mali Čentur (EŠD 1408); Pokrajinski Muzej Koper: Ljubljana, Slovenia, 2015; Available online: https://www.academia.edu/37228939/Analiza_lidarskih_podatkov_za_lokaciji_Veliki_in_Mali_C_entur_ES_ D_1408_(accessed on 27 November 2020).

95. Lozić, E. Arheološka Interpretacija Lidarskih Podatkov za Območje Volčji Grad-Arheološko Najdičče Debela Griža; Vahta d.o.o.: Ljubljana, Slovenia, 2016; Available online: https:/ / www.academia.edu/37228901/Arheolos_ka_interpretacija_lidarskih_podatkov_za_ obmoc_je_Volc_ji_Grad_Arheolos_ko_najdis_c_e_Debela_griz_a_ES_D_836_Strokovno_poroc_ilo_o_delu_in_rezultatih (accessed on 27 November 2020).

96. Lozić, E. Arheološka Interpretacija Lidarskih Podatkov za Širše Območje med Ambrožem (EŠD 765), Grmačo (EŠD 4740) in Cerkvencami (EŠD 17658) ter Arheološki Območji Vojščica-Tabor (EŠD 4734) in Sela na Krasu—Gradišče Podgrac (EŠD 25710); Občina MirenKostanjevica: Ljubljana, Slovenia, 2016; Available online: https:/ / www.academia.edu/37228949/Arheolos_ka_interpretacija_ lidarskih_podatkov_za_s_irs_e_obmoc_je_med_Ambroz_em_ES_D_765_Grmac_o_ES_D_4740_in_Cerkvencami_ES_D_17658_ ter_arheolos_ki_obmoc_ji_Vojs_c_ica_Tabor_ES_D_4734_in_Sela_na_Krasu_Gradis_c_e_Podgrac_ES_D_25710_(accessed on 27 November 2020).

97. Lozić, E. Analiza in Arheološka Interpretacija Lidarskih Podatkov Zavarovanega Območja Spomenika Kazlje-Gradičče Vahta; Občina Sežana: Ljubljana, Slovenia, 2018; Available online: https:/ /www.academia.edu/37284279/Analiza_in_arheolos_ka_interpretacija_ lidarskih_podatkov_zavarovanega_obmoc_ja_spomenika_Kazlje_gradis_c_e_Vahta_EŠD_7283_z_okolico (accessed on 27 November 2020).

98. Howard, P. Archaeological Surveying and Mapping. Recording and Depicting the Landscape; Routledge: London, UK; Routledge: New York, NY, USA, 2006; ISBN 978-0-203-41751-5.

99. Ainsworth, S.; Bowden, M.; McOmish, D.; Pearson, T. Understanding the Archaeology of Landscapes: A guide to Good Recording Practice; English Heritage: London, UK, 2007.

100. Banning, E.B. Archaeological Survey; Springer: New York, NY, USA, 2002. [CrossRef]

101. Doneus, M.; Briese, C.; Kühtreiber, T. Flugzeuggetragenes Laserscanning als Werkzeug der archäologischen Kulturlandschaftsforschung. Das Fallbeispiel “Wüste” bei Mannersdorf am Leithagebirge, Niederösterreich. Archaol. Korresp. 2008, 38, 137-156.

102. Briese, C.; Pfennigbauer, M.; Ullrich, A.; Doneus, M. Radiometric Information from Airborne Laser Scanning for Archaeological Prospection. Int. J. Herit. Digit. Era 2014, 3, 159-178. [CrossRef]

103. Sevara, C.; Wieser, M.; Doneus, M.; Pfeifer, N. Relative Radiometric Calibration of Airborne LiDAR Data for Archaeological Applications. Remote Sens. 2019, 11, 945. [CrossRef]

104. Monterroso-Checa, A. Geoarchaeological Characterisation of Sites of Iberian and Roman Cordoba Using LiDAR Data Acquisitions. Geosciences 2019, 9, 205. [CrossRef]

105. Lieskovský, T.; Faixová Chalachanová, J. The assessment of the chosen LiDAR data sources in Slovakia for the archaeological spatial analysis. In Advances and Trends in Geodesy, Cartography and Geoinformatics II; Molčíková, S., Hurčiková, V., Blišt'an, P., Eds.; CRC Press: Boca Raton, FL, USA; Taylor \& Francis Group: London, UK; Taylor \& Francis Group: New York, NY, USA, 2020; pp. 190-195.

106. Strijkers, R.; Cushing, R.; Vasyunin, D.; de Laat, C.; Belloum, A.S.Z.; Meijer, R. Toward Executable Scientific Publications. Procedia Comput. Sci. 2011, 4, 707-715. [CrossRef]

107. Li, K.; Greenberg, J.; Dunic, J. Data objects and documenting scientific processes: An analysis of data events in biodiversity data papers. J. Assoc. Inf. Sci. Technol. 2019, 71, 172-182. [CrossRef] 